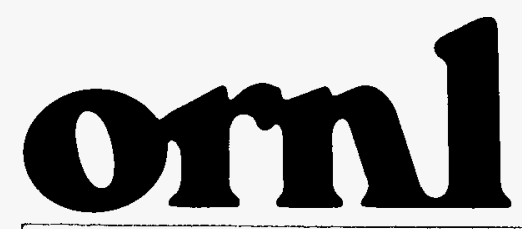

OAK RIDGE NATIONAL LABORATORY

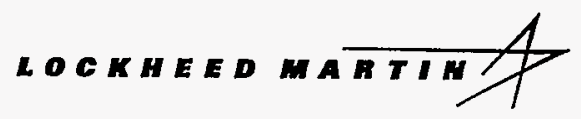

\title{
Methodology for the Evaluation of a 4000 -Home Geothermal Heat Pump Retrofit at Fort Polk, Louisiana
}

\author{
P. J. Hughes \\ J. A. Shonder \\ D. L. White \\ H. L. Huang
}

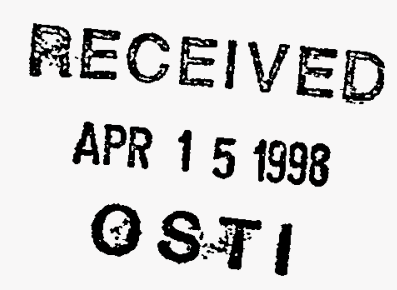


This report is available to DOE and DOE contractors from the Office of Scientific and Technical Information, P.O. Box 62, Oak Ridge, TN 37831; prices available from (423) 576-8401. Available to the public from the National Technical Information Service, U. S. Department of Commerce, 5285 Port Royal Rd., Springfield, VA 22161.

This report was prepared as an account of work sponsored by an agency of the United States Government. Neither the United States nor any agency thereof, nor any of their employees, makes any warranty, express or implied, or assumes any legal liability or responsibility for the accuracy, completeness, or usefulness of any information, apparatus, product, or process disclosed, or represents that its use would not infringe privately owned rights. Reference herein to any specific commercial product, process, or service by trade name, trademark, manufacturer, or otherwise, does not necessarily constitute or imply its endorsement, recommendation, or favoring by the United States Government or any agency thereof. The views and opinions of authors expressed herein do not necessarily state or reflect those of the United States Government or any agency thereof. 


\section{DISCLAIMER}

Portions of this document may be illegible electronic image products. Images are produced from the best available original document. 
ORNL/CON-462

\title{
Methodology for \\ the Evaluation of a 4000-Home Geothermal Heat Pump Retrofit at Fort Polk, Louisiana
}

Oak Ridge National Laboratory

P. J. Hughes

J. A. Shonder

D. L. White

H. L. Huang

Date Published—March 1998

\author{
Prepared by \\ OAK RIDGE NATIONAL LABORATORY \\ Oak Ridge, Tennessee 37831-6285 \\ managed by \\ LOCKHEED MARTIN ENERGY RESEARCH CORP. \\ for the \\ U.S. DEPARTMENT OF ENERGY \\ under Contract No. DE-AC05-96OR22464
}




\section{ACKNOWLEDGMENTS}

The authors gratefully acknowledge the financial support of the Strategic Environmental Research and Development Program, a U.S. Department of Defense program jointly implemented with the Department of Energy (DOE) and the Environmental Protection Agency, as well as the financial support of DOE and Climate Master, Inc. The technical program manager for this work was Lew W. Pratsch of DOE, Energy Efficiency and Renewable Energy, Office of Utility Technologies. The authors would also like to thank the many people whose cooperation made this work possible. Alexander Houtzager of Army-HQDA-Housing Division supported the concept of obtaining better data on geothermal heat pumps from large projects in military housing (i.e., once-in-a-lifetime opportunities). Bill Sullivan of Sandia National Laboratory (SNL) provided the initial contacts developed during his previous geothermal heat pump demonstration at Fort Polk. Commander Harmon of the U.S. Army Engineer Division-Huntsville provided a copy of the Fort Polk bid documents and the resultant performance contract between the Army and Co-Energy Group. Greg Prudhomme from Army Engineering and Housing at Fort Polk provided the necessary coordination to allow the installation of field data collection systems on the base. Gary Phetteplace of the U.S. Army Cold Regions Laboratory shared the available information from the SNL-sponsored geothermal heat pump demonstration at Fort Polk, which the Cold Regions Laboratory implemented. Tom Mitchell, President of Co-Energy Group, pledged the full cooperation of his company and its subcontractors. Bob Howell, manager of the Co-Energy Group project office at Fort Polk, provided access to locally licensed tradesmen to support installation of the field data collection systems at the base. Richard Gordon, engineering consultant to Co-Energy Group, provided information on the housing characteristics, feasibility stage estimates of energy savings, and designs of the retrofit measures. 


\section{.}




\section{CONTENTS}

1. INTRODUCTION $\ldots \ldots \ldots \ldots \ldots \ldots \ldots \ldots \ldots \ldots \ldots \ldots \ldots \ldots \ldots \ldots \ldots \ldots \ldots \ldots$

2. DESCRIPTION OF THE BASE $\ldots \ldots \ldots \ldots \ldots \ldots \ldots \ldots \ldots \ldots \ldots \ldots \ldots \ldots \ldots \ldots \ldots \ldots$

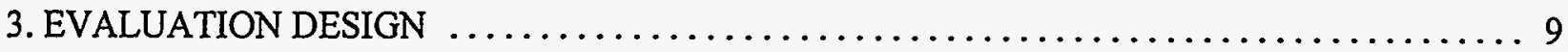

4. FIELD DATA COLLECTION AND ANALYSIS $\ldots \ldots \ldots \ldots \ldots \ldots \ldots \ldots \ldots \ldots \ldots \ldots$

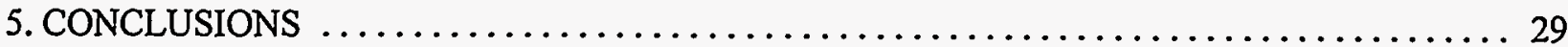




\section{FIGURES}

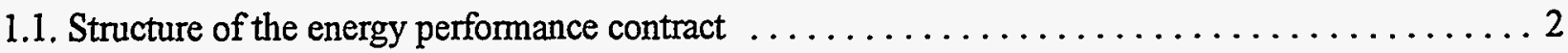

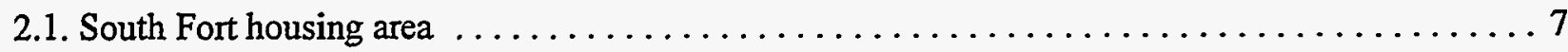

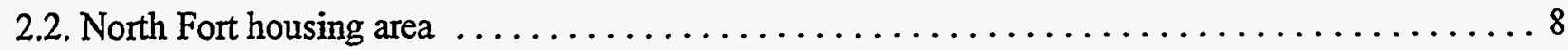

3.1. Sampling frames and levels of measurement. $\ldots \ldots \ldots \ldots \ldots \ldots \ldots \ldots \ldots \ldots \ldots \ldots$

3.2. Number of housing units by year of construction. $\ldots \ldots \ldots \ldots \ldots \ldots \ldots \ldots \ldots \ldots \ldots \ldots \ldots$

3.3. Number of buildings by number of units per building. $\ldots \ldots \ldots \ldots \ldots \ldots \ldots \ldots \ldots \ldots \ldots \ldots$

4.1 Pre-retrofit daily electrical energy use for typical feeder serving all-electric housing. $\ldots \ldots \ldots \ldots 18$

4.2 Pre-retrofit daily electrical energy use for typical feeder serving gas/electric housing. . . . . . . 19

4.3 Pre-retrofit daily electrical energy use for typical all-electric building. $\ldots \ldots \ldots \ldots \ldots \ldots 21$

4.4 Pre-retrofit daily electrical energy use for typical gas/electric building. $\ldots \ldots \ldots \ldots \ldots \ldots 22$

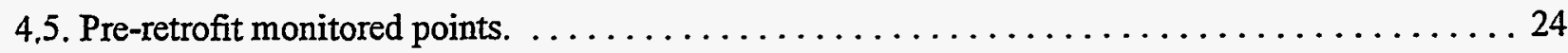

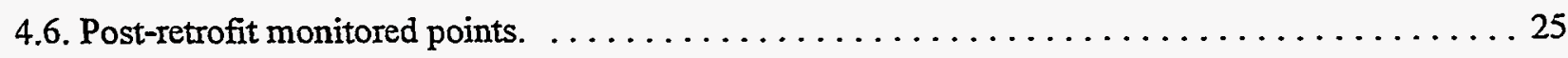

\section{TABLES}

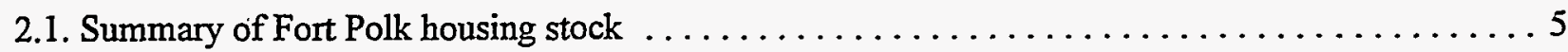

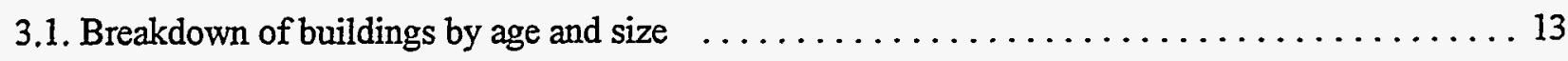

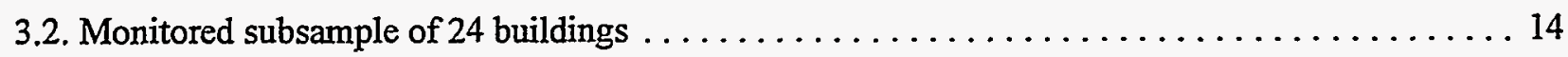

4.1. Data points for typical Level 1 , pre- and post-retrofit $\ldots \ldots \ldots \ldots \ldots \ldots \ldots \ldots \ldots \ldots \ldots \ldots \ldots$

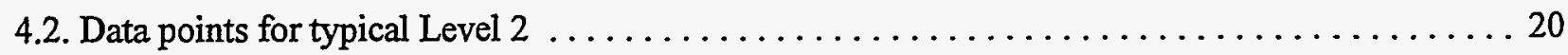

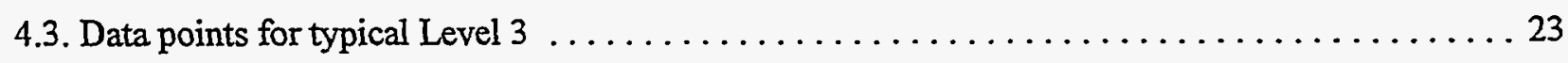




\section{INTRODUCTION}

The U.S. Army and a private energy service company are developing a comprehensive energy efficiency project to upgrade the family housing at Fort Polk, Louisiana. The project includes converting the space conditioning systems of more than 4000 housing units to geothermal (or ground-source) heat pumps (GHPs). This interim report describes the methodology of the evaluation associated with this project, including the field monitoring that has been conducted at the base.

\subsection{BACKGROUND}

The Strategic Environmental Research and Development Program (SERDP) was created by the National Defense Authorization Act of 1990 to address the long-term energy and environmental concerns of DOD. Funds for the SERDP program are authorized in six thrust areas, specifically clean-up, compliance, conservation, energy conservation/renewable energy, global environmental change, and pollution prevention.

One of the primary objectives of the energy conservation/renewable energy thrust area is to promote the demonstration of GHPs by DOD. DOD is the single largest consumer of electricity in the United States, and the costs of heating, cooling, and water heating in its facilities make up about one quarter of its total annual electricity budget. GHPs can potentially reduce electricity costs as well as maintenance costs. This project will help establish to what extent these savings materialize at Fort Polk.

Even after energy and maintenance cost savings are proven, major impediments to the use of GHPs by DOD will remain. Facility managers are generally unaware of the technology and its operating characteristics, and there is a lack of trained personnel to design, install, operate and maintain the equipment. These factors lead to difficulties in specifying and procuring equipment, and services such as installation and operation and maintenance (O\&M), within the DOD procurement process. This project may contribute to overcoming these barriers as well.

DOD needs more confidence in methods to estimate the financial value created when GHPs are placed into service, and more confidence in GHP design and construction methods and O\&M cost estimates, before it can prudently invest significant resources in in GHPs throughout its complex. The statistically valid data from Fort Polk will go a long way toward providing a foundation on which to build such confidence.

The Fort Polk demonstration opportunity exists because the U.S. Army and Co-Energy Group (a private energy service company, or ESCO) have entered into a shared energy savings performance contract. Under the terms of the contract, the ESCO will arrange private investment of about $\$ 18$ million to finance the comprehensive energy efficiency upgrades in the family housing units. In return, the Army will pay the ESCO about $77 \%$ of the energy savings over 20 years. Under a separate term of the agreement, the Army will also pay the ESCO a specified fee per housing unit per month over the 20 years to maintain the measures installed that require maintenance (e.g., heating, cooling, lighting, etc.). This maintenance payment is also about $77 \%$ of the baseline maintenance cost. 


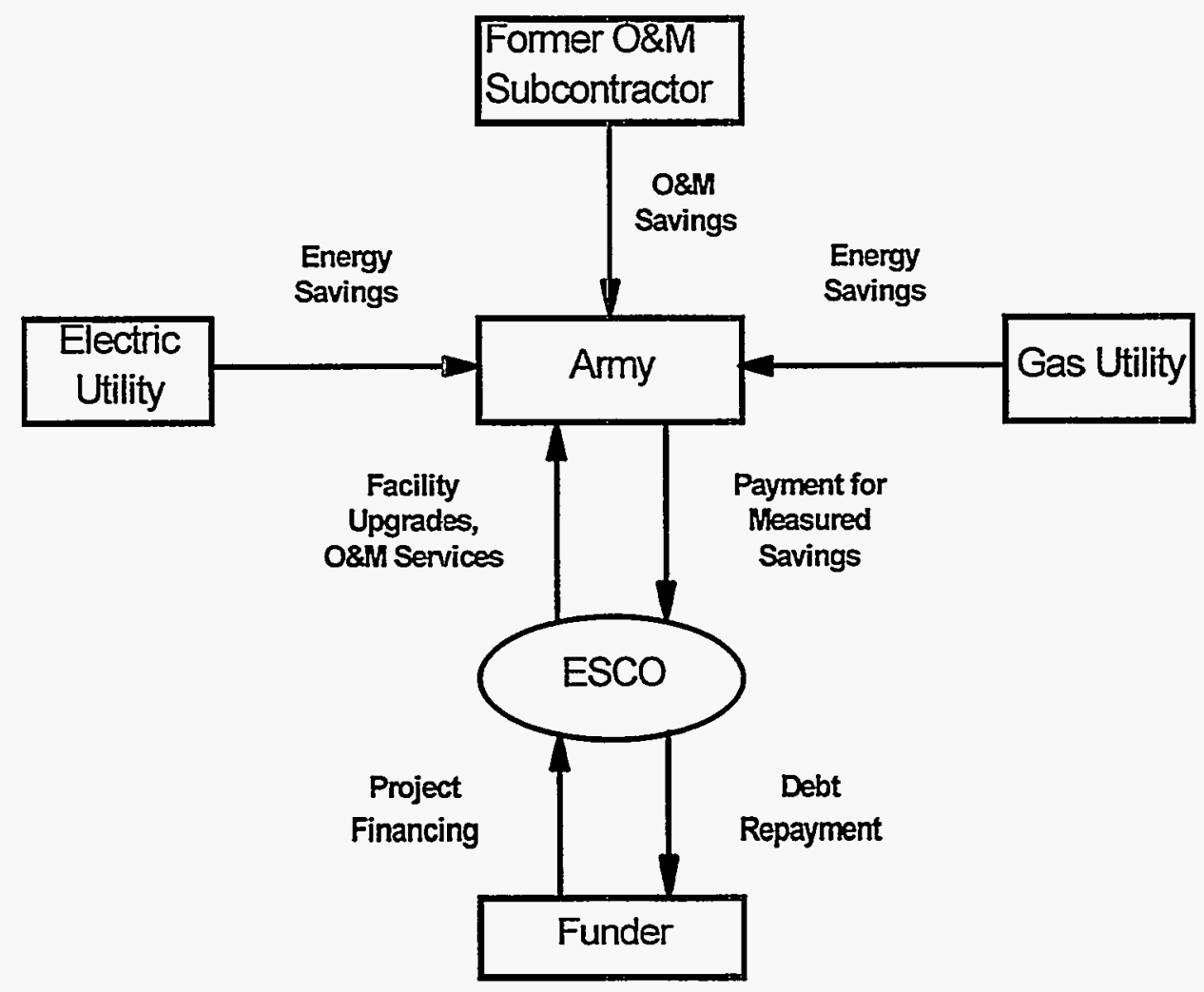

Fig. 1.1. Structure of the energy performance contract.

A variety of energy performance contract structures are in common use; the one used at Fort Polk is illustrated in Fig. 1.1. ESCO responsibilities include surveys, feasibility studies, design, financing, construction, and maintenance. The ESCO and Army agreed on estimated energy and maintenance savings, how savings would be verified, how actual savings would be shared, and who was responsible for what (e.g., the ESCO would be responsible for continued efficient performance of the measures installed, and the Army would be responsible for maintaining continued occupancy levels in the housing). The energy consumption of the housing area will be measured with community-wide metering recorded monthly, and energy savings will be estimated by subtracting recorded values from values estimated with a weather-normalized algorithm derived from the multiyear baseline data. The estimated energy savings and verification with measurements on pilot units were used by the ESCO to secure thirdparty financing. The "actual" savings, as determined by the agreed-upon M\&V approach, determines the level of payment from the Army to the ESCO on a monthly basis (with the exception of the maintenance payment, which is stipulated in the contract). Further details of the ESPC have been presented by Aldridge (1995).

Performance contracts must be acceptable not only to the ESCO and the customer but also to the party that finances the project, since the contract's terms are critical to a financier's risk. Base closings and retail wheeling of electricity were among the issues raised by the funder during its due diligence review. They will likely be issues in any future projects of this sort. Several missions have been 
consolidated at Fort Polk since downsizing began, so the Army was able to commit to contract language to resolve the base closing issue. With regard to retail wheeling, the Army chose to reserve the right to shop for less expensive power for the base, but agreed to reopen negotiations with the ESCO if a significant change occurred. The electric utility in this case chose not to contribute energy efficiency incentives to the project. Had the utility been involved, retaining Fort Polk as a customer might have been a factor in the negotiation. It is significant to note that other federal customers have agreed in energy savings performance contracts (ESPCs) to assume the rate risk and to base ESCO payments on current rates stipulated in the contract.

Fort Polk offers a unique opportunity to obtain statistically valid data establishing the energy, demand, and O\&M savings associated with GHPs in military housing. The authors believe the results of this project will also have relevance to public and private housing in general. The goals and objectives of the evaluation project at Fort Polk are summarized in the following section.

\subsection{GOALS AND OBJECTIVES}

The overall SERDP GHP Program objectives are (1) to develop awareness within DOD about GHPs, (2) to demonstrate GHP benefits to DOD, (3) to provide technical assistance and training, and (4) to provide GHP systems specification and procurement assistance.

Oak Ridge National Laboratory's (ORNL's) military family housing-related objectives in support of the overall SERDP GHP Program are (1) to determine statistically valid energy, demand, and O\&M impacts of GHPs applied to military housing at Fort Polk; and (2) to improve the DOD capability to evaluate, design, install, operate, and maintain GHPs in military family housing.

Although its development is not part of this project, the authors believe that a framework is needed for conducting a national evaluation (or meta-analysis) across the various GHP applications and demonstrations. The Fort Polk project has been structured to contribute data to such a national evaluation, which would yield reliable engineering and implementation methods to evaluate, design, install, operate, and maintain GHPs in housing, military housing included.

With reliable GHP engineering and implementation methods, DOD would have the tools necessary to appropriately match implementation options (e.g., in-house design, construction, and O\&M or outsourcing of functions separately or together) and funding sources (e.g., appropriations, private financing arranged by ESCOs, utility incentives, etc.) to the individual needs of military housing facilities. 


\section{DESCRIPTION OF THE BASE}

Located in west-central Louisiana just outside of Leesville, Fort Polk is the site of the Joint Readiness Training Center (JRTC) that trains personnel from the Army, Air Force, Navy, and Marine Corps, as well as hosting country and civilian personnel, in airlift, close-air support, resupply, and battlefield combat missions. Fort Polk is also home to other units with varied military missions, such as the 2nd Armored Cavalry Regiment, the 108th Air Defense Artillery Brigade, and the 42nd Field Artillery Brigade. The 300-square-mile facility includes military offices, training centers, equipment and storage warehouses, a hospital, miscellaneous military facilities, and residential housing units.

While the base population varies with the requirements of national defense, about 9800 military personnel are currently assigned to Fort Polk, supported by more than 2000 civilian employees. Altogether some 23,000 military personnel and family members live in on-base housing. Of these, about 12,000 live in family housing.

\subsection{EXISTING METERING}

The electrical consumption for the entire Fort is measured by a single utility-maintained billing meter. However, 17 electric distribution feeds, each with submeters, serve the residential areas of the base. These submeters are read manually by Fort staff for internal utility cost allocation purposes (and now also for the performance contract $\mathrm{M} \& \mathrm{~V}$ ). The residential submeters were calibrated by nonmilitary personnel in 1992. Current transducers, which step down the primary electrical feeds, are used by the submeters.

Natural gas consumption at the Fort is measured by a single utility-maintained billing meter. Submeters isolating residential natural gas consumption are not available, but after the ESCO construction is completed, the housing will be all-electric, except for cooking in units that originally used gas for cooking.

\subsection{HOUSING UNITS}

There are 4003 individual residential units at the facility. The Fort Polk residential housing stock consists of both single-family and multi-family units built in nine construction phases between 1972 and 1988. Most housing is in multi-family units, primarily either duplex or four-plex buildings. Table 2.1 summarizes the housing stock by the year of construction, the number of units, and the heating and airconditioning type.

North Fort and South Fort are two distinct housing development locations (Figs. 2.1 and 2.2). The South Fort housing area, on the south border of the facility, was constructed between 1972 and 1981 . The most recently developed (1984 to 1988) North Fort housing area is located approximately 4 miles to the north.

Single-family homes typically were constructed in a ranch-style configuration. Multi-family buildings were constructed in various arrangements including single-story ranches, side-by-side 
townhouses, and flats with a two-story configuration. Multi-family buildings were constructed with two to six units per building. Typical exterior wall construction types are brick, stucco, aluminum and vinyl siding. Foundations are typically poured slab-on-grade construction. Various types of envelope insulation and windows were installed during the different construction phases.

The units constructed in 1972 and 1975 use natural gas for space heating, domestic hot water heating, and cooking. The remaining units operate with electric service only.

Table 2.1. Summary of Fort Polk housing stock

\begin{tabular}{|c|c|c|}
\hline $\begin{array}{c}\text { Year of } \\
\text { construction }\end{array}$ & Number of units & Existing heating/air conditioning \\
\hline \multicolumn{3}{|c|}{ South Fort } \\
\hline 1972 & 260 & Gas furnace/DX air conditioning \\
\hline 1975 & 500 & Gas furnace/DX air conditioning \\
\hline 1976 & 1000 & Air-to-air heat pump \\
\hline 1977 & 651 & Air-to-air heat pump \\
\hline 1980 & 262 & $\begin{array}{l}\text { Air-to-air heat pump (solar domestic hot } \\
\text { water) }\end{array}$ \\
\hline 1981 . & 200 & Air-to-air heat pump \\
\hline \multicolumn{3}{|c|}{ North Fort } \\
\hline 1984 & 200 & Air-to-air heat pump ( economizer) \\
\hline 1987 & 581 & Air-to-air heat pumps (economizer) \\
\hline 1988 & 349 & Air-to-air heat pumps \\
\hline Total & 4003 & (1290 buildings) \\
\hline
\end{tabular}

\subsection{DESCRIPTION OF THE RETROFIT}

Under the terms of the performance contract, the ESCO is responsible for feasibility verification, design, financing, construction, and maintenance of the comprehensive energy efficiency upgrades to the existing 4003 housing units at Fort Polk. The housing improvements to be implemented are summarized in the next paragraph.

GHPs will replace existing air-source electric heat pumps and combinations of natural gas furnaces and central electric air conditioners. Because of the size of the heat pump order, the ESCO was able to negotiate specifications for the GHP units to improve efficiency and minimize installation labor. Electric and gas domestic hot water (DHW) heaters will be replaced with new electric units except in cases where existing electric units have significant service life remaining. In housing units where GHPs and water 
heaters are proximate to each other, GHP desuperheaters will transfer recovered heat to the water tanks. Lighting retrofits include a combination of delamping of existing fixtures, and replacement of other fixtures with compact fluorescent lights. Low-flow shower heads are to be installed in all units. Attic insulation is to be installed as needed. Water tank insulation wraps and other weatherization measures may be implemented as appropriate.

The GHPs are the major energy conservation measure. GHP system design has been completed using load calculation, equipment selection, and energy models for each of the existing 66 unique housing unit configurations. The final vertical ground heat exchanger sizes were selected from among four independent professional recommendations.

Approximately $75 \%$ of the GHPs will be equipped with DHW desuperheaters, which route recovered heat to the water tank by means of a small potable water recirculator. In cooling mode, this recovered heat would otherwise be rejected to the ground. In heating mode, the ground is the source of the recovered heat (i.e., the heating/water heating GHPs will operate for more hours than heating-only GHPs would, reducing tank resistance element operating hours). 


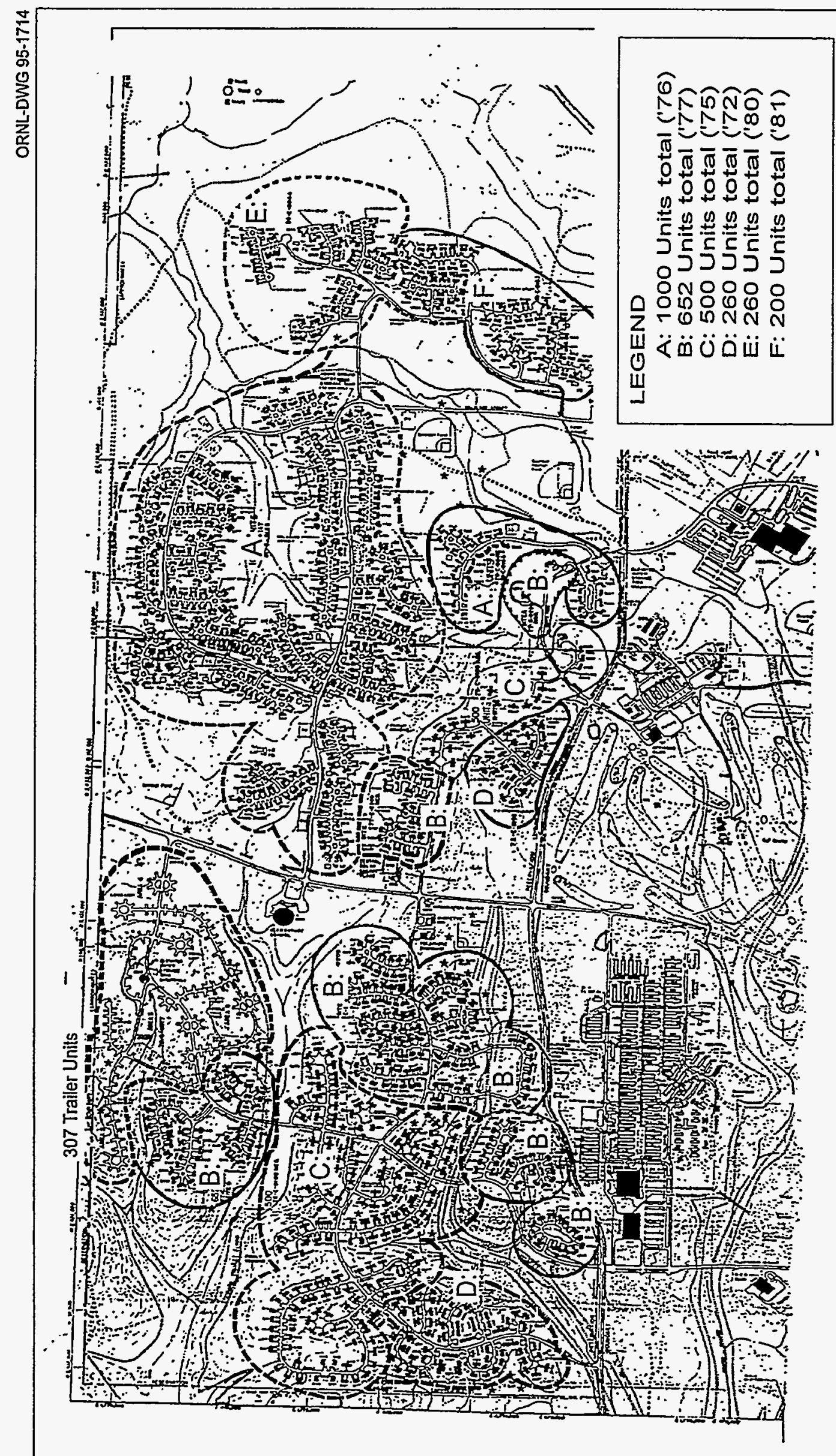




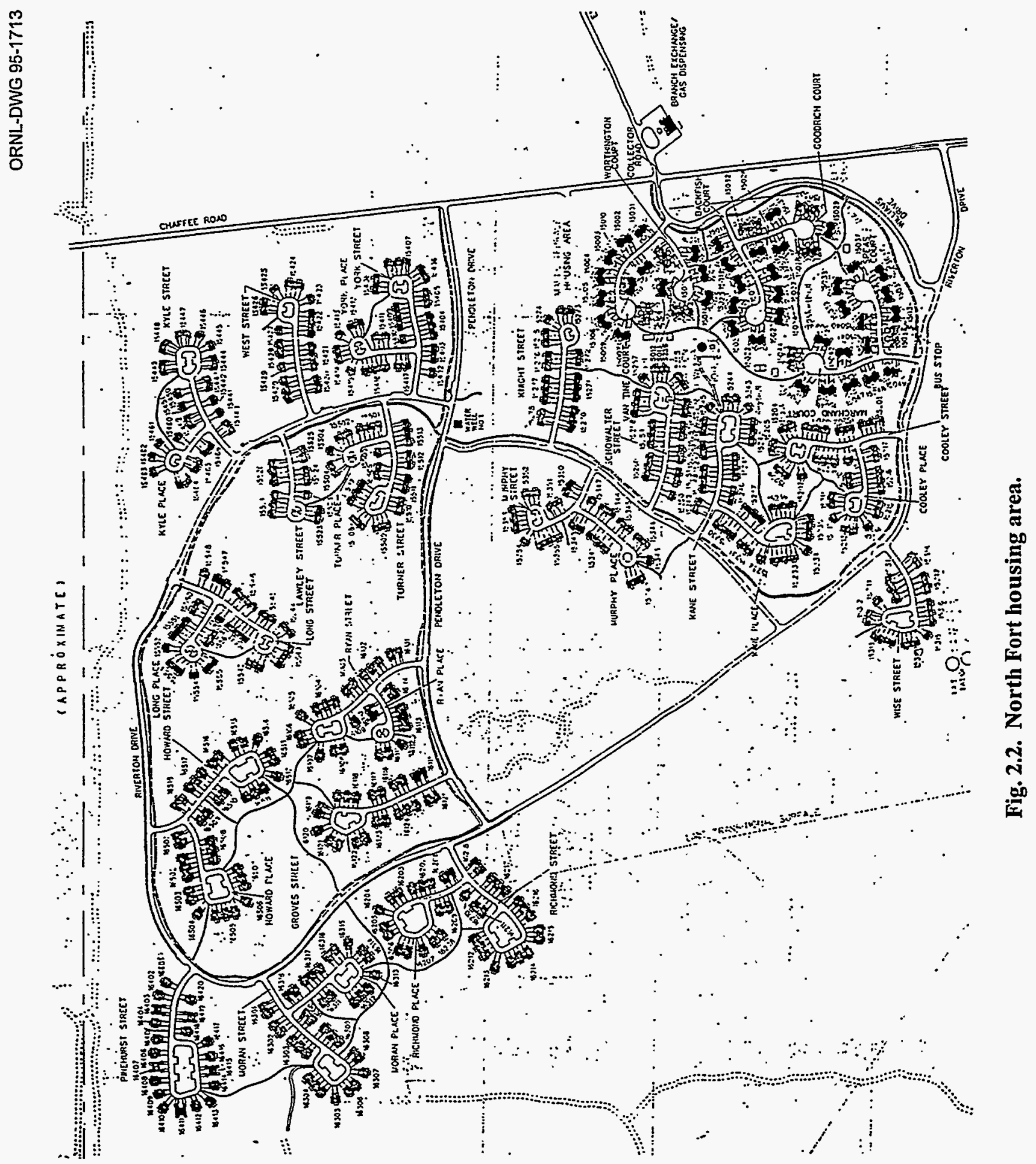




\section{EVALUATION DESIGN}

The evaluation design was developed on an expedited basis to meet project requirements. At the time the project was initiated, the ESCO planned to begin construction in June 1994 and complete construction in 10 months. Under that scenario, any pre-retrofit summer peak data would have had to be obtained in the summer of 1994 . The project funding actually was received in mid-August 1994. The evaluation was designed and monitored subsamples were mostly installed by the end of September 1994. Monitoring was fully installed by the end of October. In actuality, construction was delayed until March 1995 as the Army, ESCO, and the funding source negotiated over issues such as base closings and retail wheeling.

The evaluation design is required to meet several technical challenges and still be implementable within the likely multiyear funding resources available. The technical challenges are all related to meeting the objective of determining statistically valid energy, demand, and O\&M impacts of GHPs applied to military housing at Fort Polk.

One technical challenge is to arrive at a design that can be implemented without interfering with the performance contract. This challenge led to a "pre-retrofit/post-retrofit" design, since all of the housing is being treated, leaving no suitable untreated control group. It also led to independent community-wide electric metering to obtain 15-minute-interval electric data and to avoid interfering with the measurement and verification associated with the performance contract (monthly manual readings of consumption). A second technical challenge is to separate GHP impacts from the comprehensive energy efficiency project impacts. This led to the requirement for some monitoring of individual GHP units at the end-use level. A third technical challenge is to determine statistically valid impacts. The ratio of GHP impacts to total impacts will vary at the housing unit level because of construction vintage, building size, variations in measures installed by the ESCO, and occupancy effects. Therefore, sampling at the housing unit level is required. A fourth technical challenge is to estimate GHP O\&M impacts. This led to a census of the outdoor units (heat pumps or air conditioners) that were replaced by the GHPs to establish pre-retrofit replacement rates for those units.

The following sections describe the overall evaluation approach, the sampling frame and data description, the sampling design and sample selection, the survey data, and the O\&M data.

\subsection{APPROACH}

For the electrical energy and demand impact evaluation, ORNL is using the common technique of a nested multi-tiered evaluation design. The evaluation maintains strong internal statistical validity by sampling buildings by construction vintage and size, monitoring all apartments in the sampled buildings, selecting an even smaller subsample of those buildings for expanded metering of apartments at the enduse level, and expanding sampled impacts to the housing population where they can be compared with community-level metering.

The field measurement approach includes three nested levels of site monitoring, with each level building on the preceding level of measurement. Level 1 addresses the housing community or project (i.e., the performance contract) as a whole; Level 2 isolates the information for individual apartments in sampled buildings; and Level 3 focuses specifically on the performance impacts of the GHPs via end-use 
measurements in a subset of the Level-2 apartments. All three levels are designed to record electrical energy and demand data before the retrofits occur (pre-retrofit) and after (post-retrofit). In addition, the base-wide utility-maintained billing meter information is available to the project.

Figure 3.1 illustrates the sampling frames and levels of measurement. The entire residential housing population consists of 1290 buildings (single- and multi-family structures) and 4003 individual housing units.

Level-1 metering includes 15-minute-interval data from submeters on each of the 17 electrical distribution feeds into the housing area. Some of these distribution feeds (or combinations of them) map exactly into single construction vintages, allowing comparisons between expanded sampled impacts and monitored population impacts at the vintage population level as well as at the community-wide population level, in some cases.

The Level-2 monitored subsample will consist of 24 buildings and 71 housing units selected from the population. Level-2 metering includes 15-minute-interval data for the apartment, as well as for the heating and cooling end use (the pre-retrofit outdoor unit, the post-retrofit GHP), at all 71 housing units.

The Level-3 monitored subsample will be a technical sample of 8 buildings and 29 housing units selected from the Level-2 sample to receive more extensive end-use metering in addition to the Level-2 metering.

ORNL's approach to the O\&M impact evaluation is to develop an independent estimate of the O\&M cost baseline (i.e., costs expected if the retrofits had not taken place). A census was taken of preretrofit outdoor units (heat pumps or air conditioners) to establish replacement rates for the outdoor units. The data from this census, plus Army and ESCO data, will be used in an analysis to estimate what O\&M costs would be over the 20 years in the absence of the performance contract. The analysis approach will

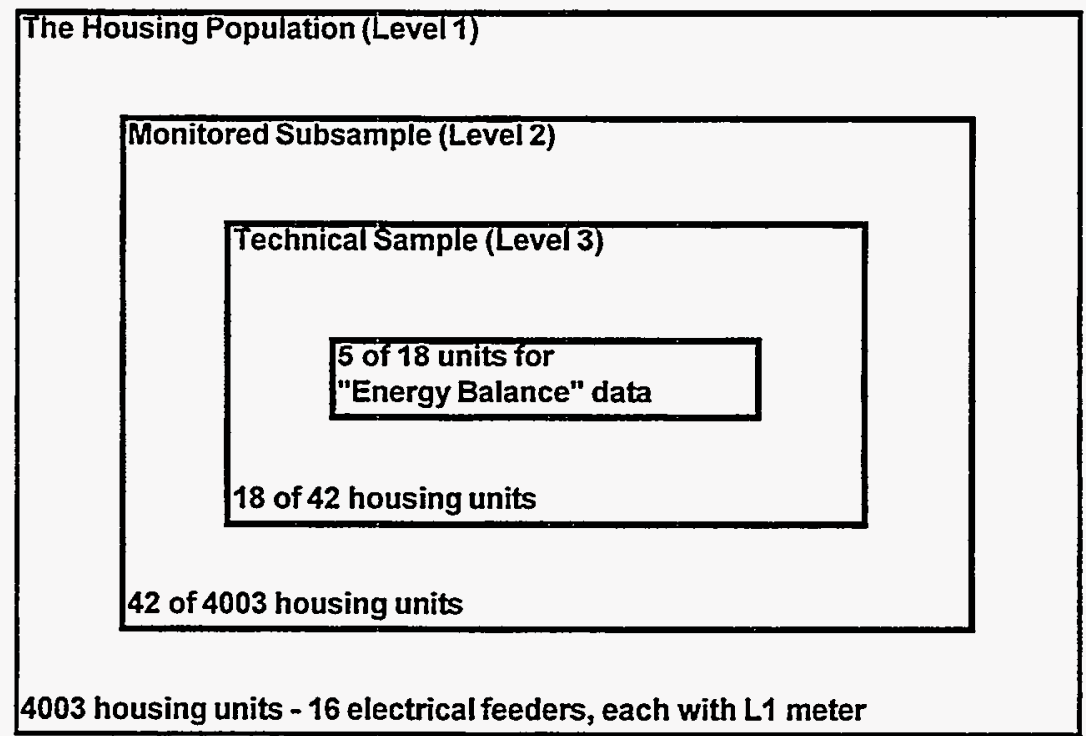

Fig. 3.1. Sampling frames and levels of measurement. 
borrow heavily from previous work done by Alabama Power and the Electric Power Research Institute (EPRI) on air-source heat pumps (Lovvorn, 1985; Pientka, 1987).

\subsection{SAMPLING FRAME AND DATA DESCRIPTION}

The family housing stock at Fort Polk consists of 1290 residential buildings with a total of 4003 housing units. Initial review of the data revealed that sufficient information was not available for building number 426 . Consequently, it was eliminated from the study. Four buildings were found to have one dwelling unit facing a different street from all other units in that same building. The unique design of these four buildings raised the concern that they might have significantly different energy characteristics from the other buildings. Therefore, they were also excluded from the database.

The ESCO-conducted experimental pretests of GHPs piloted the comprehensive package of retrofits in several dwelling units so that demonstrated energy savings would be available to support efforts to arrange the financing. Because energy savings from the building will be treated as a whole, and savings from buildings with pilot units cannot be measured on the same basis, it was determined that these buildings should not be included in the sampling frame either. Thirteen buildings were eliminated from the database for this reason. Therefore, the final Fort Polk sampling frame consists of 1272 buildings.

A total of 880 buildings, approximately $69 \%$ of the entire Fort Polk sampling frame, were constructed in the 1970s. The year with the largest number of buildings constructed was 1976, when 404 structures were built. Figure 3.2 shows the number of housing units constructed in each contract year for the Fort Polk housing.

About $50 \%$ of the 1272 buildings in the sampling frame are duplexes (two-unit buildings). The next highest number, about $30 \%$, are four-plexes (four-unit buildings). Figure 3.3 presents information about the number of buildings by size (measured by the number of dwelling units in the building).

\subsection{SAMPLING DESIGN AND SAMPLE SELECTION}

Because of the structural differences among buildings constructed in various years and potential variations in energy usage among buildings of different sizes, a stratified sampling approach was taken in this study. The year of construction (AGE) was grouped into four categories. In terms of building size, three variables were considered: (1) number of units in a building, (2) number of bedrooms in a building, and (3) square footage of living space within a building. Analysis of the data indicated strong correlations existed among these three variables; that is, the variables are providing essentially the same information. Therefore, the number of units per building (SIZE) was selected for simplicity. Buildings were classified into three size categories: one to two units, three to five units, and six or more units. The breakdown of buildings by age and size is given in Table 3.1 .

Since no information was available on energy use, variations in building energy savings among all 12 age/size combinations were assumed to be the same. The overall sample size needed to draw valid results from the Fort Polk study was estimated as if it were selected for a single group (i.e., the entire population). Based on the coefficient of variation of energy savings in other military family housing units (Levins and Ternes, 1994) it was estimated that a sample size of 24 buildings would be necessary 


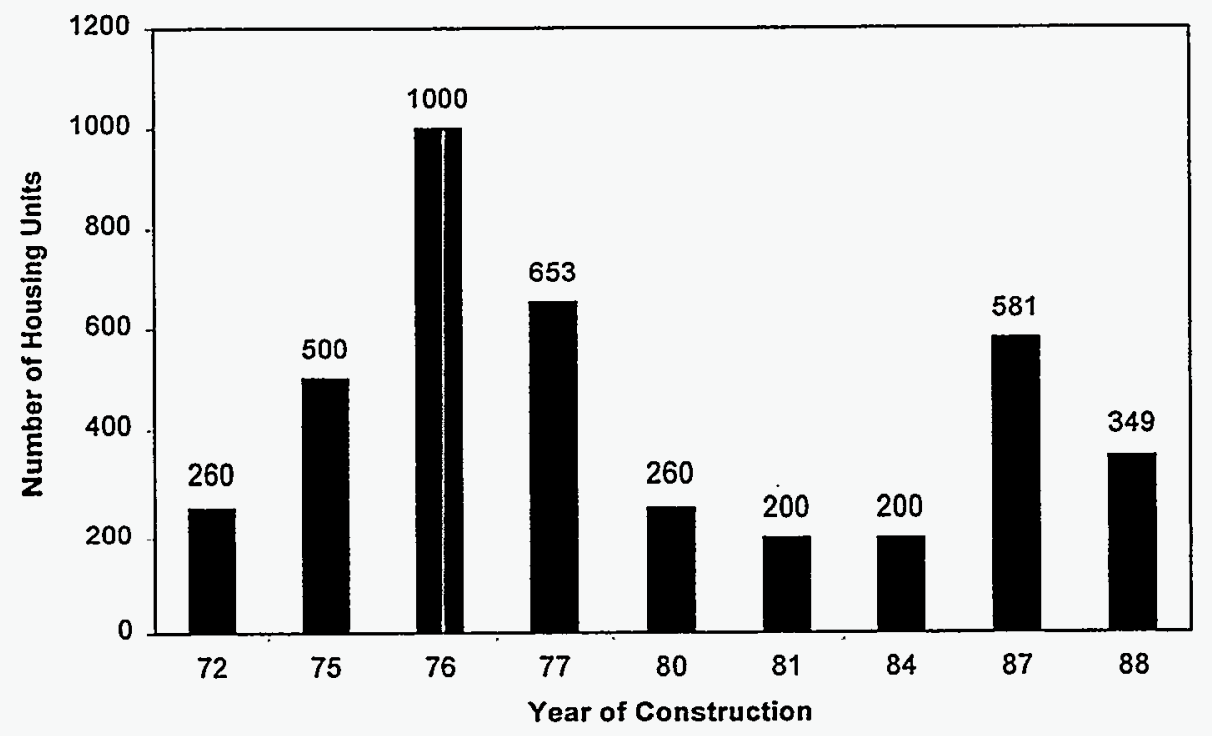

Fig. 3.2. Number of housing units by year of construction.

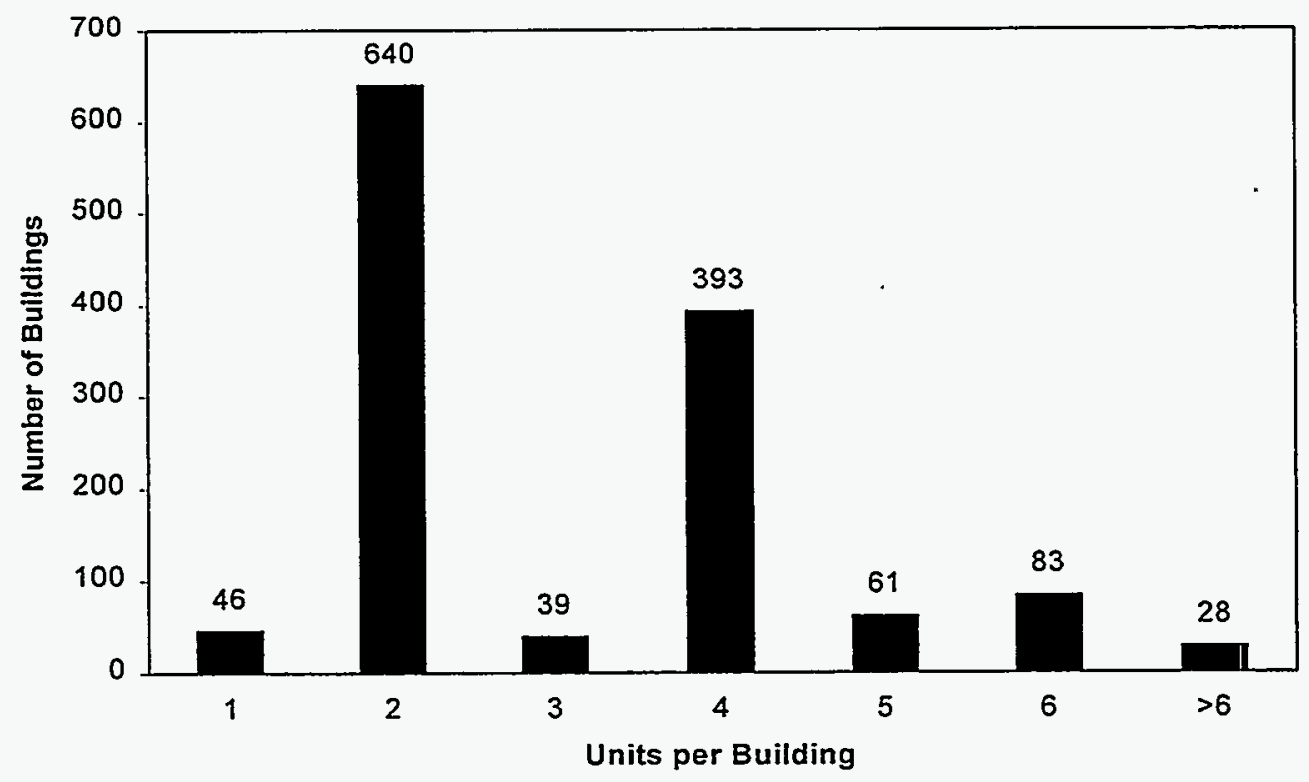

Fig. 3.3. Number of buildings by number of units per building. 
to determine the mean energy use before and after the retrofits at the $95 \%$ confidence level. In future studies on other military bases a more refined method of sample size calculation can be developed by using the savings variation findings from the current project at Fort Polk.

Originally, a written occupancy survey was planned for a set of 200 buildings drawn at random from the 1292; however, because of strict privacy regulations protecting residents of military family housing, this survey was not carried out. The written survey sample of 200 buildings was the pool from which the Level-2 monitored subsample of 24 buildings was selected. The 24 buildings were randomly selected from among the 200, rather than allocating the 200 among the 12 AGE vs SIZE categories and then selecting randomly from each category. To accommodate the fact that some buildings may be very difficult to monitor during the site survey, ten sets of random survey samples were drawn independently from the population sampling frame. For each of these sets, a monitored subsample was also selected. These survey sample and monitored subsample pairs were provided to the field engineers. The field engineers started at the top of the pair list, and performed site surveys until they found a pair that did not pose unanticipated implementation difficulties.

For the Level-3 technical sample, eight out of the 24 Level- 2 buildings were chosen for detailed end-use metering. These were selected to include a mix of buildings by vintage, size, and location.

The locations of the Level-2 and Level-3 monitored buildings are given in Table 3.2. Note that the level of monitoring is identified in the right-hand column.

Table 3.1. Breakdown of buildings by age and size

\begin{tabular}{lrrrr}
\hline & \multicolumn{3}{c}{ Number of buildings with } & Total no. of \\
\cline { 2 - 5 } Construction year & 1 to 2 units & 3 to 5 units & 6 or more units & $\begin{array}{c}\text { Population } \\
\text { buildings }\end{array}$ \\
\cline { 2 - 5 } 1972 or 1975 & 171 & 74 & 17 & 262 \\
1976 or 1977 & 425 & 167 & 38 & 630 \\
1980 or 1981 & 4 & 81 & 10 & 95 \\
After 1984 & 86 & 171 & 46 & 303 \\
Total & 686 & 493 & 111 & 1290 \\
1972 or 1975 & & & Survey sample & 41 \\
1976 or 1977 & 26 & 12 & 3 & 96 \\
1980 or 1981 & 66 & 26 & 4 & 15 \\
After 1984 & 1 & 12 & 2 & 48 \\
Total & 14 & 26 & 8 & 200 \\
\hline
\end{tabular}


Table 3.2. Monitored subsample of 24 buildings

\begin{tabular}{|c|c|c|c|c|c|c|c|c|c|}
\hline Bldg. No. & Street & Year & $\begin{array}{l}\text { No. of } \\
\text { Units }\end{array}$ & $\begin{array}{c}\text { HP } \\
\text { Model }\end{array}$ & $\begin{array}{l}\text { Desuper- } \\
\text { heater }\end{array}$ & Attic Area & $\begin{array}{l}\text { Unit } \\
\text { Size }\end{array}$ & $\begin{array}{c}\text { No. of } \\
\text { Bedrooms }\end{array}$ & $\begin{array}{c}\text { Monitoring } \\
\text { Level }\end{array}$ \\
\hline 4808 & Reed Court & 1977 & 2 & VZ024 & 0 & 1,996 & 3,584 & 6 & 2 \\
\hline 5007 & Diamond Street & 1972 & 2 & VE030 & 1 & 2,970 & 2,970 & 8 & 2 \\
\hline 5045 & Stance LP & 1972 & 2 & VZ024 & 1 & 2,524 & 2,524 & 6 & 2 \\
\hline 5104 & Michael Drive & 1975 & 4 & VZ017 & 0 & 2,186 & 4,372 & 8 & 2 \\
\hline 5185 & Dietz Drive & 1975 & 2 & VZ024 & 1 & 3,162 & 3,160 & 8 & 3 \\
\hline 5217 & Monroe Drive & 1975 & 2 & VE030 & 1 & 3,162 & 3,160 & 8 & 2 \\
\hline 5219 & Monroe Drive & 1975 & 6 & VE030 & 1 & 5,712 & 10,158 & 24 & 3 \\
\hline 5310 & Monroe Drive & 1975 & 2 & VZ017 & 1 & 2,584 & 2,584 & 6 & 2 \\
\hline 5379 & Cline Court & 1977 & 4 & VZ017 & 0 & 3,456 & 6,692 & 12 & 3 \\
\hline 5485 & Bilger Court & 1977 & 4 & VZ017 & 0 & 2,348 & 4,696 & 8 & 2 \\
\hline 5623 & Mudry LP & 1976 & 1 & VZ024 & 1 & 1,794 & 1,794 & 4 & 2 \\
\hline 5634 & Bazydlo Street & 1976 & 1 & VZ024 & 1 & 1,794 & 1,794 & 4 & 2 \\
\hline 5805 & Warren Court & 1981 & 4 & VZ017 & 1 & 2,316 & 4,632 & 8 & 2 \\
\hline 6204 & Haag Street & 1976 & 2 & VZ024 & 1 & 1,804 & 3,456 & 8 & 3 \\
\hline 6229 & Haag Place & 1976 & 4 & VZ017 & 1 & 2,146 & 4,292 & 8 & 3 \\
\hline 6306 & Noldan Street & 1976 & 2 & VŻ024 & 1 & 1,968 & 3,548 & 6 & 2 \\
\hline 6342 & Noldan Street & 1976 & 2 & VZ024 & 1 & 1,968 & 3,728 & 8 & 2 \\
\hline 616 & Jordan Court & 1976 & 4 & VZ017 & 1 & 2,146 & 4,292 & 8 & 2 \\
\hline 6685 & Tracey Place & 1976 & 4 & VZ017 & 1 & 2,146 & 4,292 & 8 & 2 \\
\hline 6937 & Garber Court & 1980 & 5 & VZ017 & 1 & 3,776 & 5,610 & 10 & 3 \\
\hline 15314 & Wise Street & 1987 & 4 & VZ017 & 1 & 3,362 & 5,700 & 10 & 3 \\
\hline 15502 & Turner Place & 1987 & 4 & VZ017 & 1 & 3,362 & 5,700 & 10 & 2 \\
\hline 16112 & Ryan Place & 1988 & 2 & VZ024 & 1 & 1,894 & 3,238 & 6 & 2 \\
\hline 16410 & Pinehurst & 1988 & 2 & VZ024 & 1 & 1,700 & 2,542 & 4 & 2 \\
\hline
\end{tabular}




\subsection{O\&M DATA COLLECTION}

The cost of O\&M for heating, cooling, and water heating systems in housing is a major expense for the military. The military desires guidance on how to record and track pre-retrofit costs, predict postretrofit costs, and structure performance contracts or other contracts to better manage costs.

Fort Polk has had a variety of O\&M arrangements in the past, including in-house and subcontracted service. The availability of historical O\&M data sources on actions and costs will be investigated.

The ESCO assumed responsibility for all energy-systems-related O\&M in family housing about 12 months prior to the start of retrofit construction. Available records will be obtained on pre-retrofit O\&M actions and costs. In cases where the ESCO alters the housing unit conversion sequence to avoid pre-retrofit O\&M actions and costs, the avoided actions will be identified and costs estimated. ESCO willing, there will be collaboration with the ESCO to define post-retrofit O\&M record keeping systems to be maintained by the ESCO for the duration of the 20-year performance contract.

Historical O\&M practices and associated costs will be established by gathering and analyzing the available data, which may including the following:

- a census of pre-retrofit central air conditioner and air source heat pump outdoor units (performed as part of this project);

- the pre-retrofit O\&M records of the ESCO (the ESCO pre-retrofit period is now significant because of construction delays);

- notes from interviews with base personnel and previous maintenance subcontractor personnel; and

- available base and subcontractor historical records on O\&M costs and replacement costs for heating, cooling, and water heating equipment for housing.

The planned structure of the O\&M analysis, including the basis for estimating GHP O\&M impacts, is as follows:

- Document pre-retrofit O\&M actions and costs in aggregate for the conventional heating, cooling, and water heating equipment in all base housing.

- Use historical data and industry data (i.e., Alabama Power and EPRI work on air-source heat pumps) to infer (or project) what O\&M actions and costs would have been in the absence of the performance contract over the 20 years (i.e., establish a baseline).

- Use ESCO data to establish the near-term post-retrofit O\&M actions and costs in aggregate for the GHP heating, cooling, and water heating equipment in all base housing.

- Use GHP industry data to infer (or project) GHP O\&M actions and costs over the 20 years, or assume the contracted Army payments to the ESCO are a valid indication, and estimate the GHP O\&M impact by subtraction from the baseline. 


\section{FIELD DATA COLLECTION AND ANALYSIS}

The GHP project at Fort Polk provides a unique opportunity in that each of 4003 residential units is being retrofitted with a GHP. The diversity in housing stock, combined with the large housing population, allows the implementation of the statistically valid, nested, multi-tiered evaluation design described in Sect. 3.

This section describes more specifically the field data collection efforts undertaken to implement the community-wide Level-1 monitoring and the Level-2 and -3 monitored subsamples. The metering approach was designed to obtain three levels of information:

- Level 1: Project impact using community-wide electric energy and demand data, outdoor dry bulb temperature, and relative humidity.

- Level 2: Housing unit impact using total-residence and HVAC electric energy and demand data.

- Level 3: Separation of GHP from total impacts using additional electric end-use energy and demand data.

This section also describes more specifically the analysis approaches to be taken.

\subsection{PROJECT ANALYSIS: LEVEL 1}

The Level-1 metering and analysis focuses on the measurements of the impact of the project as a whole (i.e., the performance contract as applied to all housing). This includes not only the GHP impacts, but also all impacts derived from all energy conservation measures implemented via the performance contract.

The Level-1 metering installed for the evaluation parallels the existing Army submetering on each electrical distribution feed into the housing area. Fifteen-minute-interval electrical power measurements are taken at each of the 17 residential area submeters. These data are recorded on pole-mounted data loggers, and the data are remotely retrieved via telephone. For comparison, the Army manually logs cumulative readings from its submeters on a monthly basis. The Level- 1 metering collects the data points identified in Table 4.1 at 15 -minute intervals.

Table 4.1. Data points for typical Level 1, pre- and post-retrofit

\begin{tabular}{llc}
\hline Point name & \multicolumn{1}{c}{ Description } & Units \\
\hline TAO & Outdoor air dry-bulb temperature & ${ }^{\circ} \mathrm{F}$ \\
RHO & Outdoor air relative humidity & $\%$ \\
WT & Electric distribution feeder submeter energy & $(17$ \\
& separate submeters) & $\mathrm{kWh}$ \\
\hline
\end{tabular}




\section{Electrical Energy Savings Analysis}

Preliminary analysis of the Level-1 pre-retrofit data indicates that daily average temperature is the most reliable predictor of daily electrical energy use for the electrical feeders which serve family housing. Data for a typical feeder serving all-electric housing is presented in Fig. 4.1. Electrical use evidently falls into three distinct regimes, depending on average daily temperature: a heating regime, in which energy use increases with decreasing ambient temperature; a cooling regime, in which energy use increases with increasing ambient temperature; and a mid-range, in which energy use is relatively constant and does not depend on ambient temperature. Ruch and Claridge (1992) have presented similar data for commercial buildings. Such data can be fit to a dual-changepoint model, which supposes a linear relationship between daily energy use and daily average temperature for the heating and cooling regimes, and constant energy use in the mid-range. The electrical energy use $E$ for a particular day with average temperature $T$ is given by:

$$
E= \begin{cases}E_{0}+m_{1}\left(T-T_{1}\right) & \left(T<T_{1}\right) \\ E_{0} & \left(T 1 \leq T \leq T_{2}\right) \\ E_{0}+m_{2}\left(T-T_{2}\right) & \left(T>T_{2}\right)\end{cases}
$$

where $E_{0}$ is a constant corresponding to the daily energy use in the midrange, $m_{1}$ and $m_{2}$ are the respective slopes of the heating and cooling regimes, and $T_{1}$ and $T_{2}$ are the respective heating and cooling changepoints. The line in Fig. 4.1 is a dual-changepoint fit to the data presented.

Figure 4.2 presents a similar plot of daily electrical use vs daily average temperature for a feeder serving housing with natural gas heating and water heating. Here only two regimes are evident: at low ambient temperatures daily energy use is relatively constant, but above a certain changepoint energy use begins to increase with increasing temperature. Data for the feeders serving housing heated by natural gas can be fit to a single-changepoint model, which assumes constant electrical energy use below the changepoint, and a linear relationship between daily electrical energy use and daily average temperature above the changepoint. For such feeders, the daily energy use $E$ for a day with average temperature $T$ is given by:

$$
E= \begin{cases}E_{0} & \left(T<T_{1}\right) \\ E_{0}+m_{1}\left(T-T_{1}\right) & \left(T \geq T_{1}\right)\end{cases}
$$

where $E_{0}$ is a constant corresponding to the daily electrical energy use in the non-cooling regime, $m_{1}$ is the slope of energy use vs ambient temperature in the cooling regime, and $T_{1}$ is the cooling changepoint. The line in Fig. 4.2 is a single-changepoint fit to the data presented.

Pre-retrofit data on daily energy use vs daily average temperature for each feeder will be fit to either a single-changepoint or a dual-changepoint model, depending on whether the housing served is allelectric or gas/electric. After the retrofits all housing will be all-electric, so it is assumed that daily electrical use on each feeder will follow a dual-changepoint relationship. In order to correct for weather variations, annual pre- and post-retrofit energy consumption for each feeder will be normalized to a 


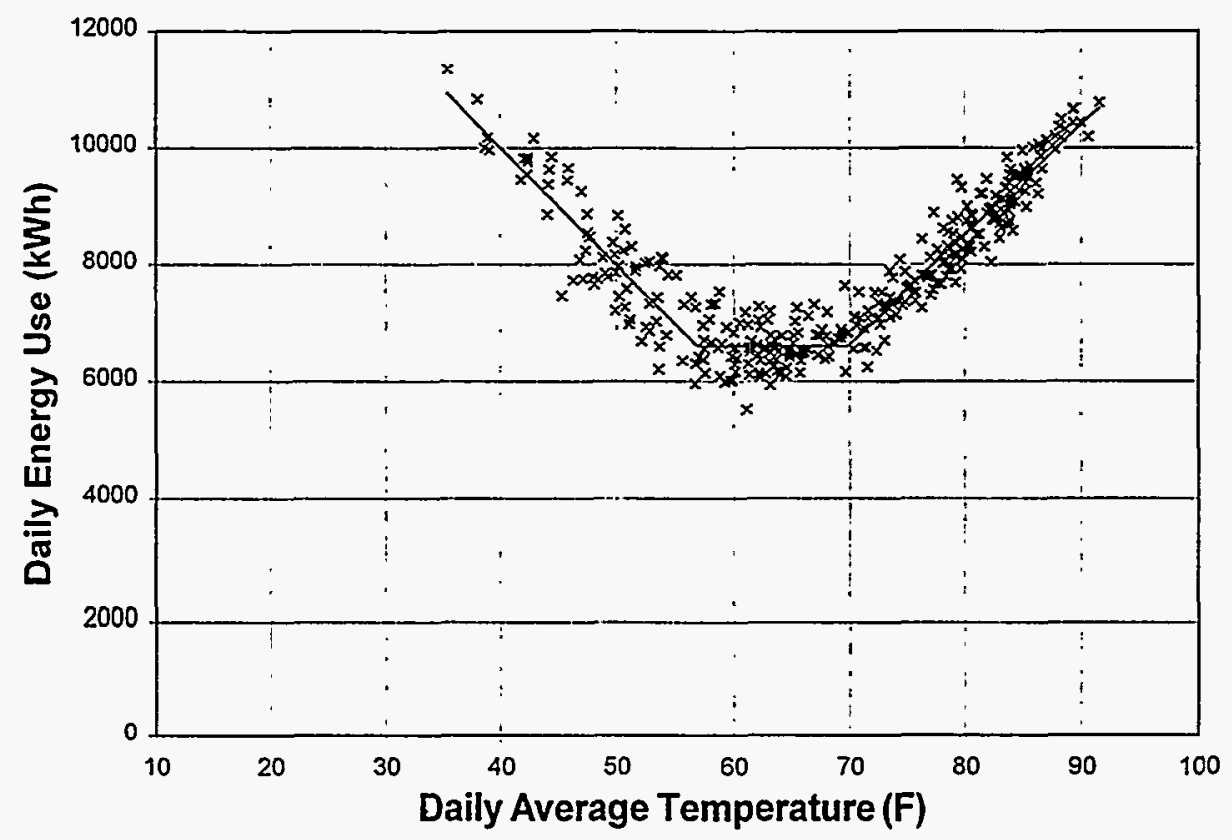

Fig. 4.1. Pre-retrofit daily electrical energy use for typical feeder serving allelectric housing.

typical meteorological year. Thus for each feeder $I$ the annual electrical energy savings $\Delta E_{i}$ will be estimated by:

$$
\Delta E_{i}=\sum_{j=1}^{365} E_{i, p r e}\left(T_{j}\right)-\sum_{j=1}^{365} E_{i, p o s t}\left(T_{j}\right)
$$

where $E_{i, p r c}\left(T_{j}\right)$ is the single- or dual-changepoint fit to the pre-retrofit data for feeder $I$, and $E_{i, \text { post }}\left(T_{j}\right)$ is a dual-changepoint fit to the post-retrofit data for feeder $I . T_{j}$ is a set of 365 daily average temperatures corresponding to the typical meteorological year. The total estimated annual electrical energy savings from the project is then the sum of the energy savings from each feeder.

For the most part, the distribution of housing by feeder corresponds to construction vintage (i.e., all housing on feeder 11 was constructed in 1975, all housing on feeder 16 was constructed in 1987, etc.). The buildings in each construction vintage are identical except for compass orientation, and the living units are the same size except for small variations between upper and lower units. Thus Level-1 data will also be used to analyze the following:

- Pre- and post-retrofit energy consumption per unit vs construction vintage.

- Pre- and post-retrofit energy consumption per unit vs floor area.

- Energy savings per ton of cooling capacity installed. 


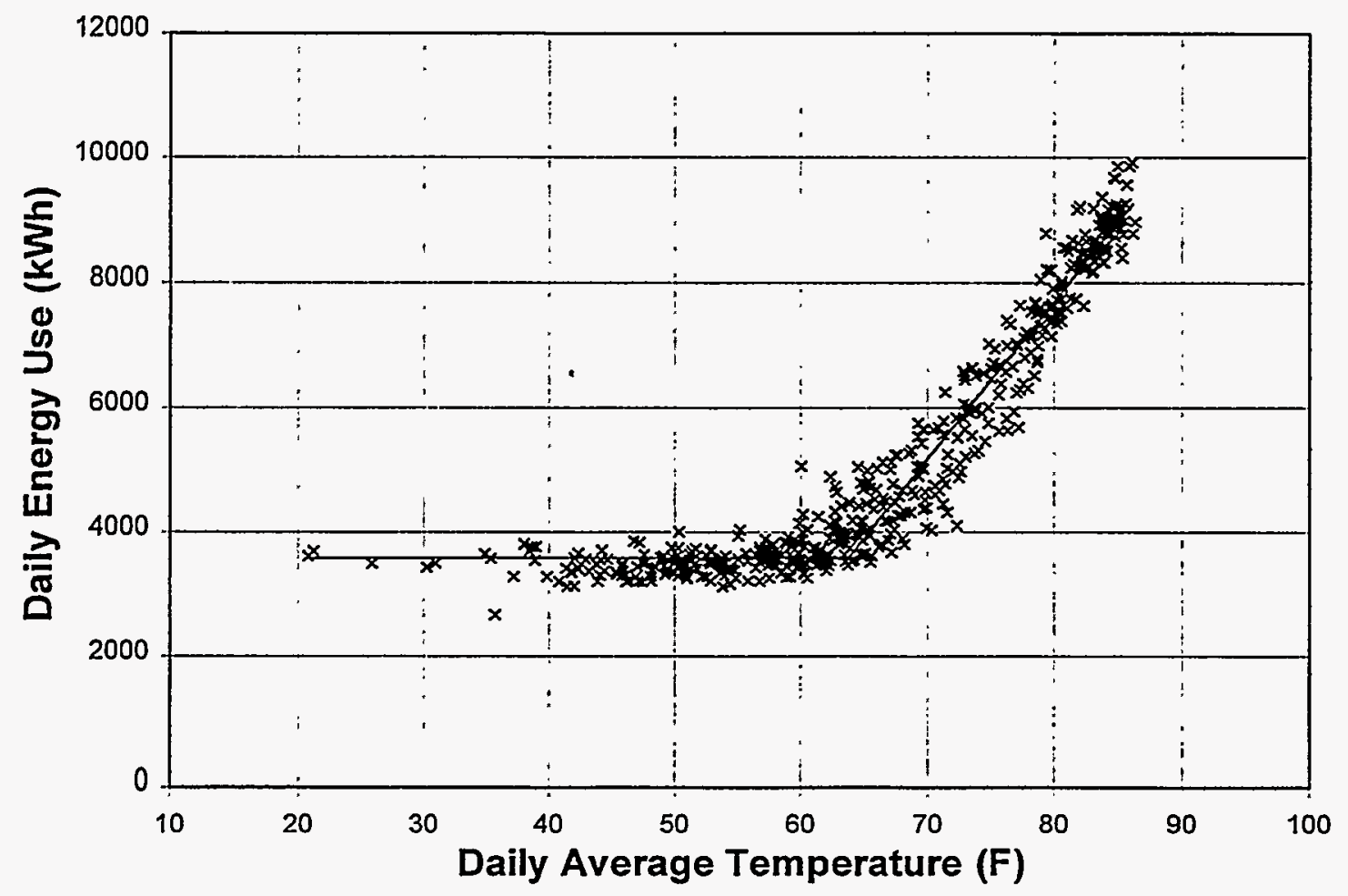

Fig. 4.2. Pre-retrofit daily electrical energy use for typical feeder serving gas/electric housing.

\section{Electrical Demand Savings Analysis}

In general, electrical demand is a complex phenomenon which depends on numerous variables such as time of day and day of the week, outdoor temperature, average temperature during a number of past hours, average temperature during a number of past days, and others. Utilities commonly use five years or more of historical data for their demand models (Kim 1982). A rigorous analysis of electrical demand savings in this project would require the development of such models for both the pre- and post-retrofit for each feeder. As in the case of annual energy consumption, the models could then be normalized to a typical meteorological year to determine the savings.

For the purposes of this evaluation, a simpler approach will be used. It is assumed that daily average temperature is the dominant variable in determining peak electrical demand. The 15-minute-interval energy consumption will be used to determine daily electrical demand profiles for each feeder. Demand profiles from three pre-retrofit and three post-retrofit days with essentially identical temperatures will be selected and used to establish three-day-average pre- and post-retrofit profiles. Demand savings will be determined as the difference between the three-day-average profiles averaged over the 4:00-5:00 P.M. time period, which corresponds to the utility's peak demand hour. As with the energy consumption data, pre- and post-retrofit electrical demand on each of the feeders will provide information on savings by construction vintage, living unit area, and installed cooling capacity. 


\section{Natural Gas Savings Analysis}

The gas energy impacts are determined as follows. The only gas metering at Fort Polk the base-wide utility-maintained billing meter, and billing data will be available to the project. The South Fort housing built in 1972 and 1975 uses gas for space heating and water heating in the pre-retrofit condition and is all-electric in the post-retrofit condition. The Level-3 monitored subsample (see Sect. 4.3) will include two buildings and eight housing units with gas in the pre-retrofit condition (see Table 3.2). At these sites, furnace and water heater runtime are part of the 15-minute-interval data, and gas-burn rate constants are estimated from nameplate data. The Level-3 data will be used to estimate pre-retrofit gas consumption at the sampled sites normalized to weather indices, and that estimate will be expanded to the gas-connected population. The weather-driven pre-retrofit estimate will equal the project impact on gas consumption, since the post-retrofit condition for heating and cooling will be all-electric. Analysis of the pre-/postretrofit gas billing data will provide another estimate for comparison, but this indicator may not be reliable because family housing may be a small part of the base-wide gas consumption, or the nonhousing gas loads may have increased.

\subsection{HOUSING UNIT ANALYSIS: LEVEL 2}

Level-2 measurements and analysis focus on isolating energy and demand impacts on a sample of housing units. The approach provides pre-/post-retrofit electric energy and demand impacts in samples defined by construction vintage and building size.

The Level-2 sample comprises 24 buildings for a total of 71 individual housing units. In each housing unit the electrical energy for the whole residence and for the major end use, the air conditioner or heat pump outdoor unit, are metered at 15-minute intervals. These data are recorded on data loggers mounted to residential buildings and the data are remotely retrieved via telephone. The Level-2 metering collects the data points identified in Table 4.2 at 15 -minute intervals.

Table 4.2. Data points for typical Level 2

\begin{tabular}{llc}
\hline Point name & \multicolumn{1}{c}{ Description } & Units \\
\hline & \multicolumn{1}{c}{ Pre-retrofit data } \\
TAO & Outdoor air dry-bulb temperature & \\
RHO & Outdoor air relative humidity & ${ }^{\circ} \mathrm{F}$ \\
WT & Whole-residence electric energy & $\%$ \\
WAC & Air conditioner or heat pump outdoor unit energy & $\mathrm{kWh}$ \\
& $\quad$ Post-retrofit data & $\mathrm{kWh}$ \\
& $\quad$. & \\
TAO & Outdoor air dry-bulb temperature & ${ }^{\circ} \mathrm{F}$ \\
RHO & Outdoor air relative humidity & $\%$ \\
WT & Whole-residence electric energy & $\mathrm{kWh}$ \\
WAC & Geothermal heat pump unit energy & $\mathrm{kWh}$ \\
\hline
\end{tabular}




\section{Electrical Energy Savings Analysis}

As with the Level-1 data, analysis of the pre-retrofit Level-2 data indicates that daily average temperature is the most reliable predictor of daily energy use in each living unit. Figure 4.3 presents data from a typical all-electric residence. The line in that figure is a dual-changepoint fit to the data, an equation similar to Eq. 4.1.

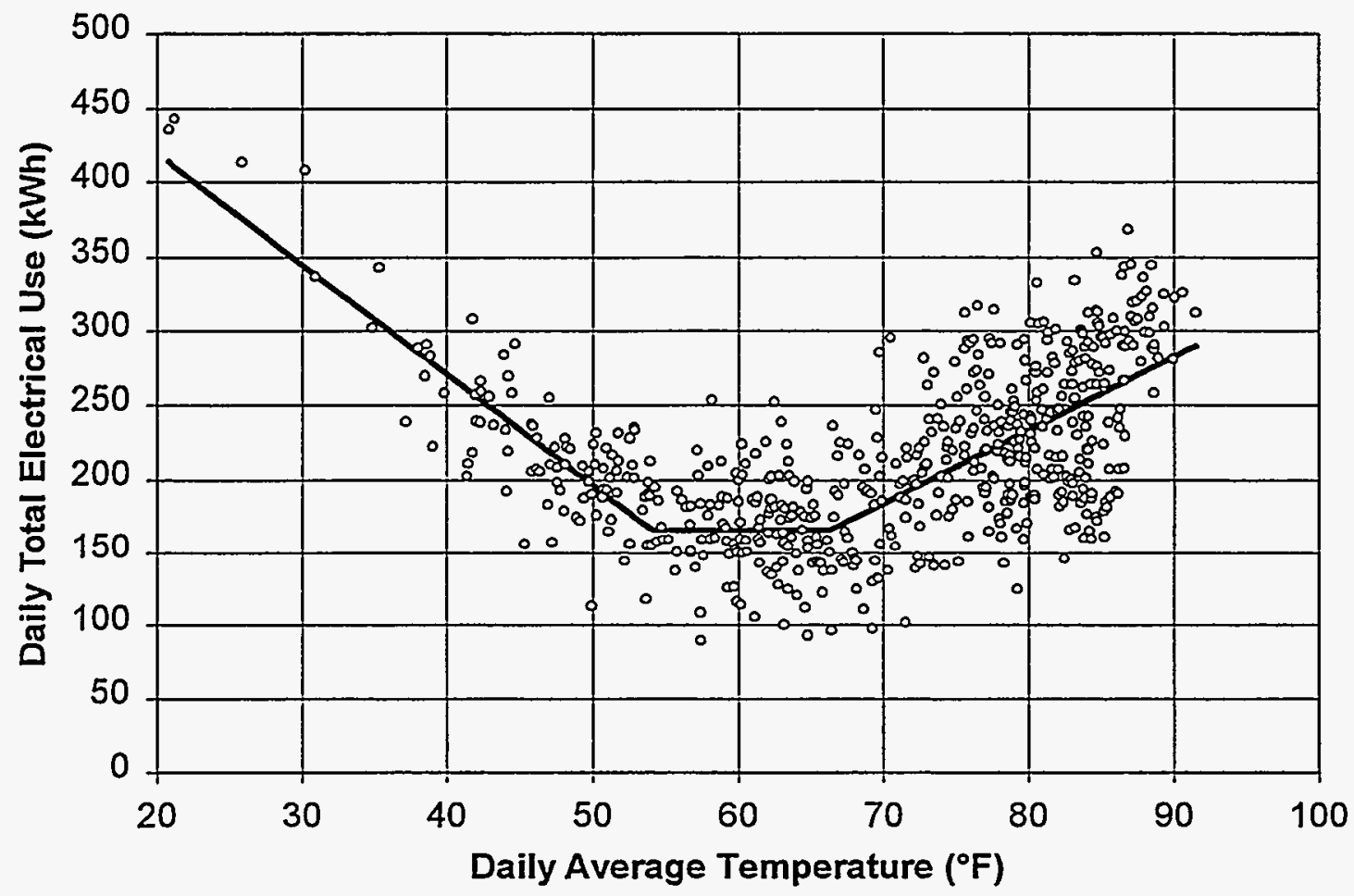

Fig. 4.3. Pre-retrofit daily electrical energy use for typical all-electric building.

Figure 4.4 presents pre-retrofit data from a typical gas/electric residence; the line represents a singlechangepoint fit to the data, an equation similar to Eq. 4.2. In order to determine the electrical energy savings for each of the 71 Level-2 residences, pre-retrofit data on daily energy use vs daily average temperature will be fit to a single- or dual-changepoint model; post-retrofit data will be fit to a dualchangepoint model. The annual energy savings for each residence $i$ will then be calculated by:

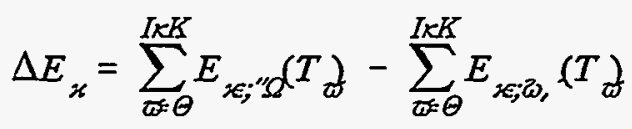

where $E_{i, p r e}\left(T_{j}\right)$ is the single- or dual-changepoint fit to the pre-retrofit data for residence $i$, and $E_{i, \text { post }}\left(T_{j}\right)$ is a dual-changepoint fit to the post-retrofit data for residence $i . T_{j}$ is a set of 365 daily average 


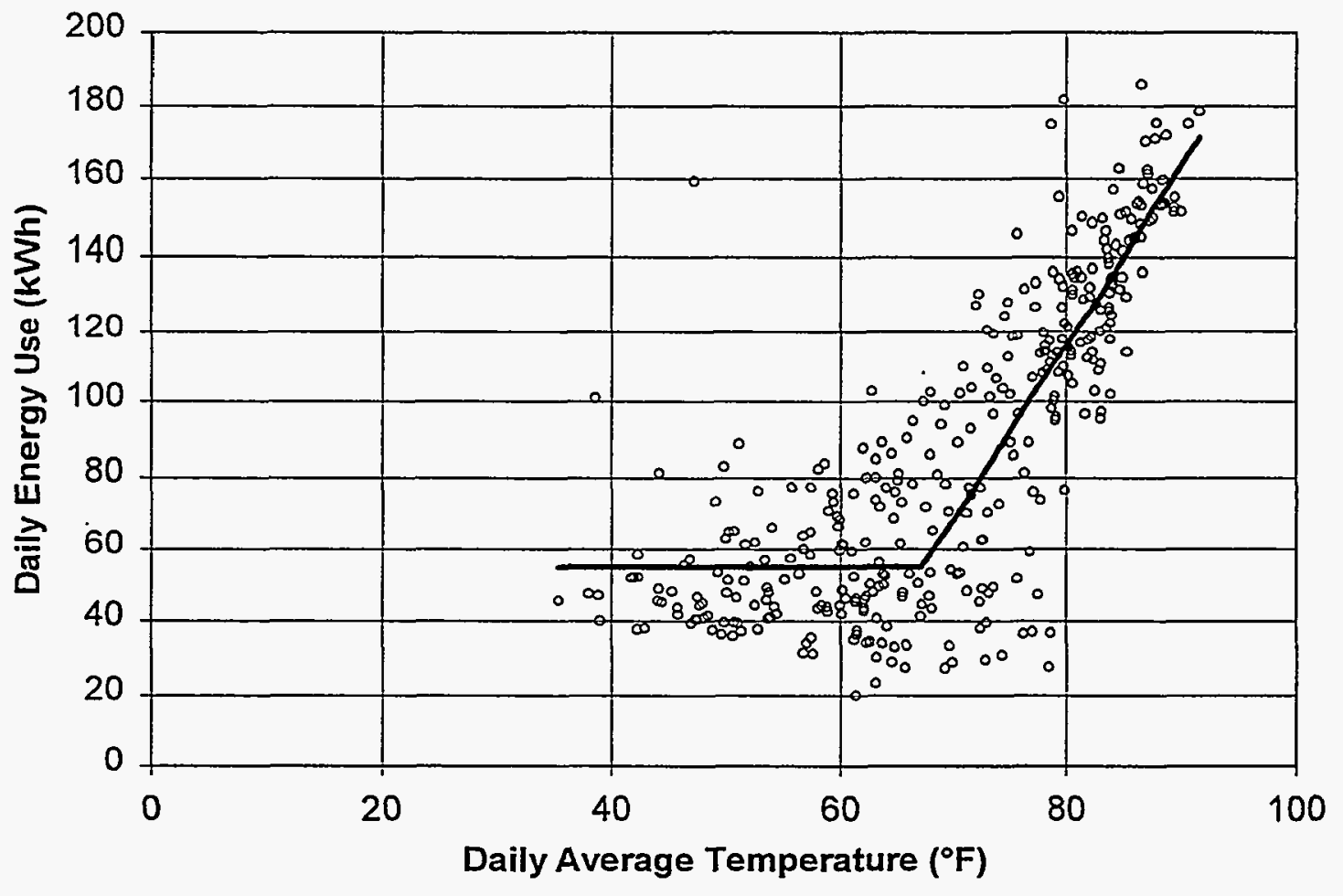

Fig. 4.4. Pre-retrofit daily electrical energy use for typical gas/electric building.

temperatures corresponding to the typical meteorological year. Similar pre- and post-retrofit fits will also be performed for the HVAC energy alone, to support determination of the proportion of the energy savings due to the GHPs.

Level-2 energy savings data will provide information on variations in energy savings by living unit area and construction vintage. An important test of statistical validity will be to scale up the pre- and post-retrofit Level-2 electrical energy use data to the Level-1 feeder data. This will be accomplished by forming weighted sums of the Level-2 electrical use data (the weighting will most likely be by floorspace). The HVAC curve-fits will be scaled up using the same weighting factors to determine the percentage of energy savings due to the GHP retrofits at the level of individual feeders and for the entire project.

\section{Electrical Energy Demand Savings Analysis}

Electrical demand savings for each of the 71 Level-2 housing units will be determined using a method similar to the Level-1 analysis. Average peak demand profiles will be obtained by averaging three peak days in the pre-retrofit and three peak days in the post-retrofit (all six days with similar temperatures). Average demand during the utility peak hour (assumed to be 4:00-5:00 P.M.) will be determined, and demand savings will be calculated by subtracting post-retrofit demand from the pre-retrofit demand. As with electrical energy use, demand from the Level-2 housing units will be scaled up to the feeder and project levels. 


\subsection{END-USE ANALYSIS: LEVEL 3}

Level-3 metering provides more end-use breakout, but does so on a much smaller sample. The additional end-use measurements are taken on a technical subset of the Level-2 sample ( 8 of the 24 Level- 2 buildings and 29 of the 71 housing units).

The Level-3 metering collects the data points identified in Table 4.3 at 15 -minute intervals. Schematics identifying the pre-retrofit and post-retrofit monitored data points are presented in Figs. 4.5 and 4.6 , respectively.

Table 4.3. Data points for typical Level 3

\begin{tabular}{lll}
\hline Point name & \multicolumn{1}{c}{ Description } & Units \\
\hline & \multicolumn{1}{c}{ Pre-retrofit data } & \\
TAO & Outdoor air dry-bulb temperature & ${ }^{\circ}$ \\
RHO & Outdoor air relative humidity & $\%$ \\
WT & Whole-residence electric energy & $\mathrm{kWh}$ \\
WAC & Air conditioner or heat pump outdoor unit energy & $\mathrm{kWh}$ \\
RB & Indoor HVAC unit blower runtime & seconds \\
RD & Water heater runtime (electric element or gas burner) & seconds \\
RFE, or & Dwelling unit electric furnace runtime, or & seconds \\
RFG & Dwelling unit natural gas furnace runtime & seconds \\
& & \\
& & \\
TAO & Outdoor air dry-bulb temperature & ${ }^{\circ} \mathrm{F}$ \\
RHO & Outdoor air relative humidity & $\%$ \\
WT & Whole-residence electric energy & $\mathrm{kWh}$ \\
WAC & Air conditioner or heat pump outdoor unit energy & $\mathrm{kWh}$ \\
RB & Indoor HVAC unit blower runtime & seconds \\
RD & Water heater runtime (electric element ) & seconds \\
TL & GHP entering temperature from ground heat exchanger (when flow is & ${ }^{\circ} \mathrm{F}$ \\
& on) & \\
\hline
\end{tabular}

Level-3 energy analysis will provide a basis for separating GHP impacts from total impacts with the following information:

- whole-residence pre-/post-retrofit electrical energy and demand impacts, .

- water heating pre-/post-retrofit electrical energy and demand impacts,

- whole-residence and end-use residential load profiles,

- separation of GHP impacts from total impacts,

- impacts in samples defined by construction vintage and building size,

- expansion of sampled impacts for comparison with community-wide or feeder-by-feeder impacts,

- whole-residence and end-use load dependence upon outdoor dry-bulb temperature and relative humidity, and

- gas pre-retrofit heating and water heating consumption in 1972 and 1975 construction. 


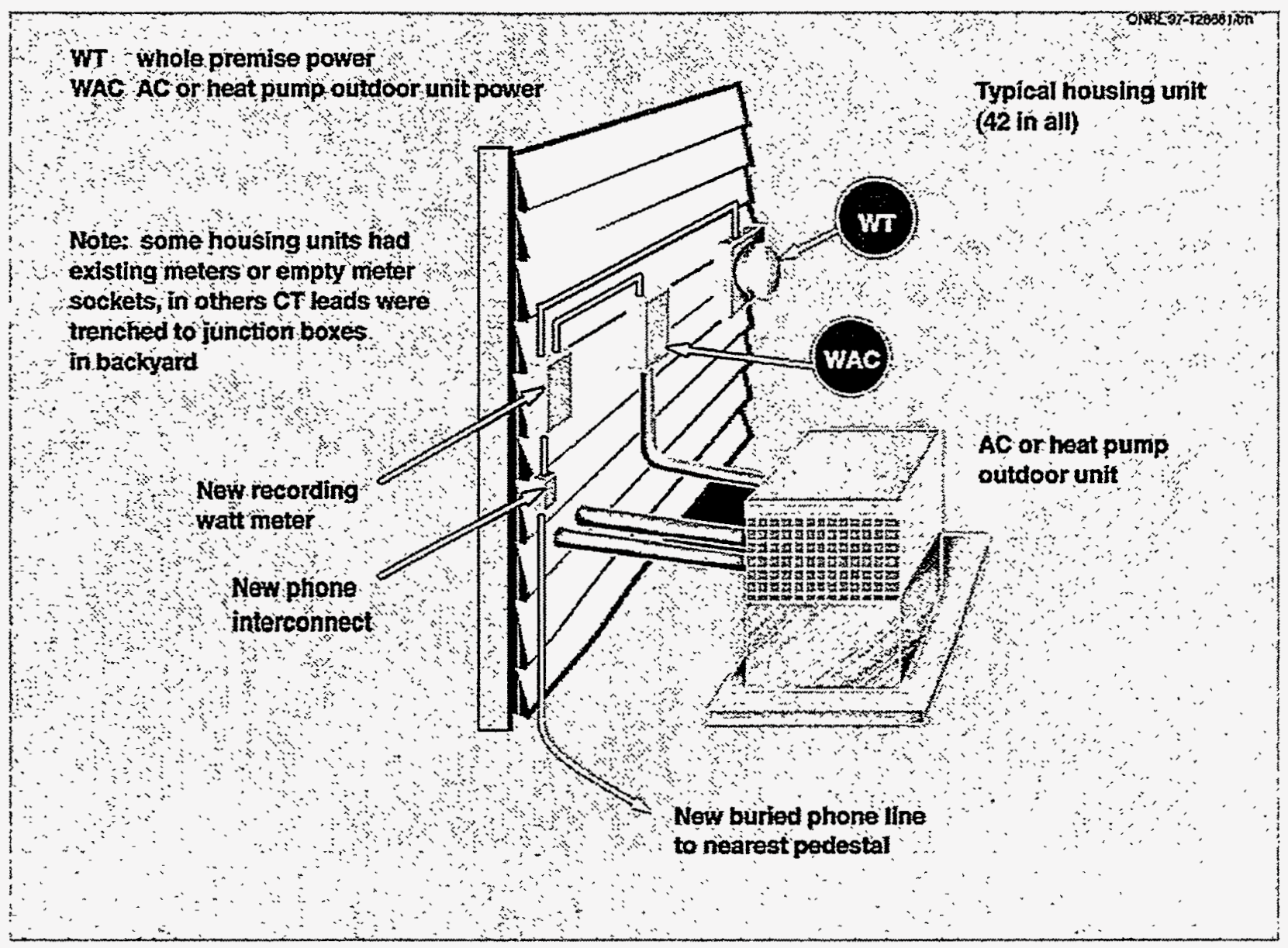

Fig. 4.5. Pre-retrofit monitored points.

The energy efficiency upgrades installed by the ESCO vary by construction vintage. All units will receive GHPs for heating and cooling. About $75 \%$ of the units will receive GHP contributions to water heating via potable water recirculation through desuperheaters. All units will receive compact fluorescent lights in some lighting fixtures, and a reduction in the number of incandescent bulbs in other fixtures. Most units will receive new electric water heaters, tank wraps, pipe wraps, and lowflow shower heads. Some of the units, especially the older ones, may receive various weatherization measures (e.g., caulking, weatherstripping, duct repairs). The ESCO is using detailed surveys and a work order system to control the measures that are installed in each unit. This information will be available to the project.

The objective of the Level-3 analysis will be to build detailed energy use models for each of the 29 monitored apartments. From the Level-2 analysis (section 4.2), pre- and post-retrofit models will exist for both daily total energy use and daily energy use for the HVAC system vs daily average temperature for each of Level-3 apartments. Level-3 data on energy use for water heating will be used to develop preand post-retrofit models of daily energy use for water heating by apartment floorspace; if significant 


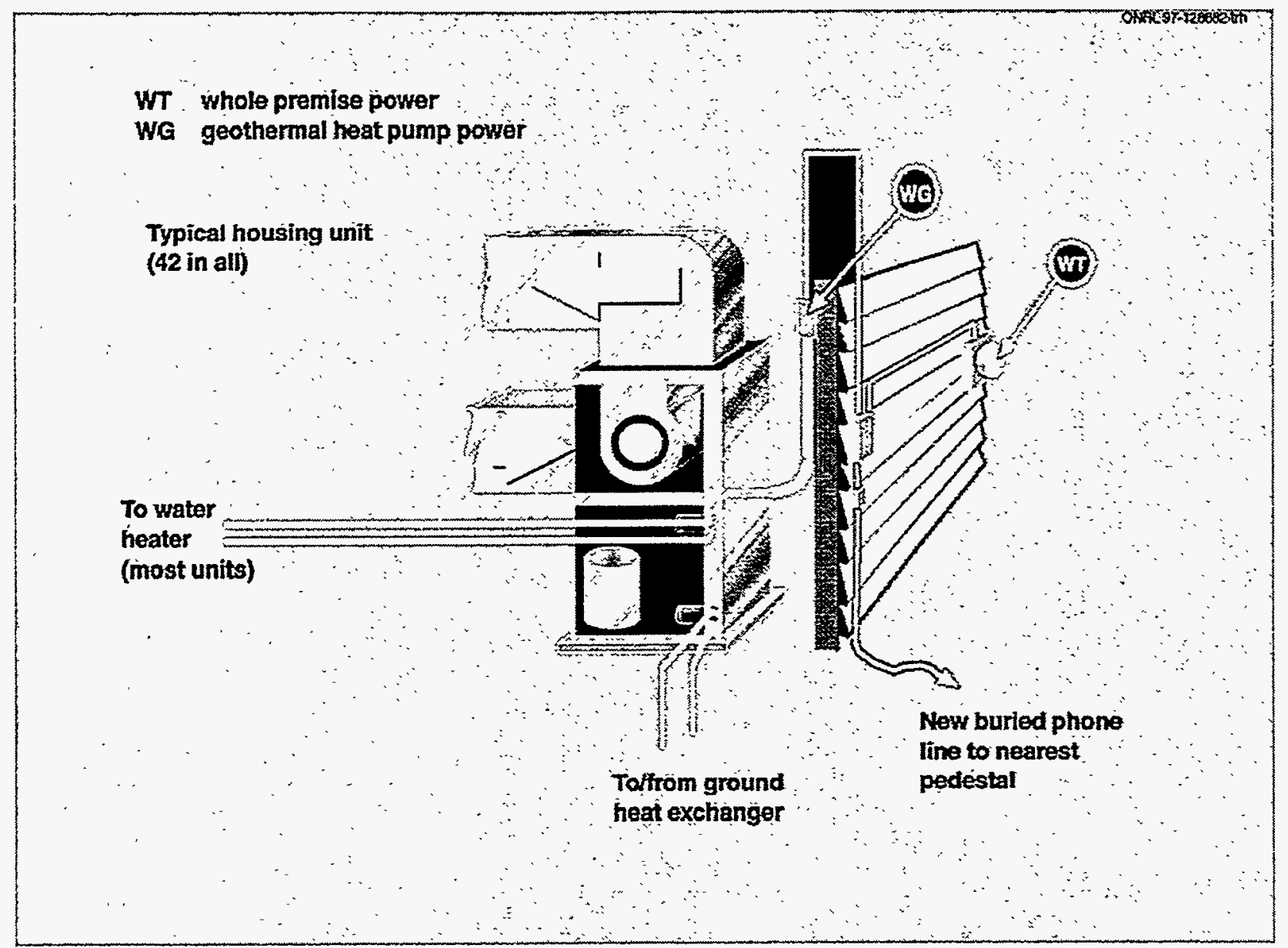

Fig. 4.6. Post-retrofit monitored points.

seasonal variations exist, this will be incorporated into the modeis as well. Post-retrofit models will be developed for apartments with and without desuperheaters.

Pre- and post-retrofit data will be available on total energy use, energy use by the HVAC system, and energy use by the water heater. Subtracting HVAC and water heating energy use from the total gives all other electrical use in the apartment, including lights, televisions, radios, etc. Since this includes the effect of the lighting retrofits, the daily pre- and post-retrofit "appliance load" will also be analyzed to determine how it varies by apartment floorspace; seasonal variations may be included in the model as well if they are found to be significant.

For each of the Level-3 apartments which was all-electric in the pre-retrofit, models of the following form will exist: 


$$
\begin{aligned}
& E_{t o t}=E_{H V A C}(T)+E_{D H W}(A)+E_{A P P}(A) \\
& E_{t o t}^{\prime}=E_{H V A C}^{\prime}(T)+E_{D H W}^{\prime}(A)+E_{A P P}^{\prime}(A)
\end{aligned}
$$

where $E_{H V A C}$ is a single- or dual-changepoint model of pre-retrofit daily energy use in the HVAC system vs daily average temperature; $E_{H V A C}^{\prime}$ is a dual-changepoint model of post-retrofit daily energy use in the HVAC system vs daily average temperature; $E_{D H W}$ and $E_{D H W}^{\prime}$ are linear functions of apartment floorspace area $A$ (and possibly including other terms to capture seasonal variations) for preand post-retrofit daily energy use for water heating; and $E_{A P P}$ and $E_{A P P}^{\prime}$ are linear functions of apartment floorspace area A (and possibly including other terms to capture seasonal variations) for preand post-retrofit daily energy use for the other electric appliances, including lighting. When weighted according to the distribution of apartment floorspace in the housing population, these models will allow determination of the proportion of total savings which are due to each retrofit measure.

\subsection{ANALYSIS WITH ENGINEERING MODELS}

DOD needs more confidence in methods to estimate the financial value created when GHPs are placed into service, and more confidence in GHP design methods. To fulfill this need, this project will use as a starting point, the design and energy estimating methods and assumptions of the ESCO and its subcontractors. In addition to establishing the actual GHP and total project impacts at Fort Polk, as explained previously, this project will answer the question "if you had it to do over again, how would you perform the GHP design and energy/demand estimating for this project?"

The ESCO designed the project using ACCA Manual J load calculation, ACCA Manual S equipment selection, and bin analysis energy models for each of the 66 unique housing unit configurations that exist at Fort Polk. These estimates were then expanded to the population based on the number of units of each type. The final vertical ground heat exchanger sizes were selected from among four independent commercially available heat exchanger sizing programs. As part of this project these methods will be brought in-house, studied, and compared with other available methods as well as with the Level-1, -2 , and -3 monitored data. These comparative analyses will result in the selection of recommended sets of methods and recommended assumptions for these methods.

The general approach will be as follows. In all apartments of one of the Level-3 buildings, additional instrumentation will be installed to monitor the operation of the ground source heat pump: ground loop inlet and outlet water temperatures, reversing valve status (heating or cooling position), desuperheater status (on/off), and indoor temperature and humidity will be monitored at 15-minute intervals. A detailed dynamic simulation of each apartment, its installed GHP, and controls, will be developed and calibrated to the field-monitored data. These dynamic models will then be used to generate the space conditioning load data required for the four ground loop sizing software packages used by the ESCO. 
A dynamic model of the ground heat exchanger will also be incorporated into the model for each apartment using the duct ground heat storage model (Hellstrom et al., 1996) developed at the University of Lund, Sweden. The model was chosen because it is well documented, validated, and considers multibore interactions and long-term (multiyear) effects. Since the Lund model requires as input the heat transfer properties of the soil, calibrating the model to field-collected data on inlet and outlet water temperatures will allow the soil properties at the site to be determined. Since the ESCO based its ground loop designs on soil properties measured using conventional methods, this "reverse engineering" of soil properties will provide a useful comparison.

The dynamic energy use model for each apartment and its associated GHP with ground loop and controls, will provide a calibrated benchmark for comparison with other commercially available ground loop sizing software. For example, if it is found that the ground loops are oversized, the dynamic models can be used to determine the correct size which would give a specified maximum entering water temperature. This will provide information on the accuracy and usefulness of more practical sizing methods. 


\section{CONCLUSIONS}

A statistically valid, nested multi-tiered evaluation strategy has been developed to determine the energy savings due to an energy savings performance contract at Fort Polk, Louisiana. The evaluation will determine the overall energy savings from the project, and the proportion of these savings due to each conservation retrofit, the most important of which is the installation of a geothermal heat pump in each residence. Based on maintenance records collected before the retrofits, the evaluation will also estimate the Army's pre-retrofit maintenance cost, and determine the maintenance cost savings associated with the ESPC. Based on detailed data collected at one building, the evaluation will also develop a detailed dynamic model of the building/GHP/ground loop/controls system which will be used as a benchmark for comparison with commercially available ground loop sizing software. 


\section{REFERENCES}

Aldridge, David R. 1995. "Developing a Shared Savings Energy Contract," Heating/Piping/Air Conditioning, pp. 61-63 (September).

Kim, Gene. 1982. "Con Edison Hourly Electric Load Model," Approaches to Load Forecasting: Proceedings of the Third EPRI Load Forecasting Symposium, pp. 144-167, Electric Power Research Institute (July).

Levins, W.P., and M. P. Ternes. 1994. "Energy Efficiency in Military Housing: Monitoring to Support Revitalization Guidebook," Oak Ridge National Laboratory, ORNL/TM-12723 (November).

Lovvorn, N. C., and C. C. Hiller. 1985. "Survey of Heat Pump Life," Electric Power Research Institute, Report No. EM-4163 (July).

Pientka, K. A. 1987. "Heat Pump Service Life and Compressor Longevity in a Northern Climate," ASHRAE Transactions vol. 87-09-01, pp. 1087-1090.

Ruch, David, and David E. Claridge. 1992. "A Four-Parameter Change-Point Model for Predicting Energy Consumption in Commercial Buildings," Journal of Solar Energy Engineering, Vol. 114, pp. 7782 ( May). 


\title{
DISTRIBUTION
}

\author{
Internal
}

1. R. N. Baugh

2. V. D. Baxter

11. M. G. Madgett

12. M. M. Martin

3. M. A. Brown

13. H. A. McLain

4. J. M. Campbell

5. J. E. Christian

6. G. E. Courville

7. P. D. Fairchild

8. S. K. Fischer

9. P. J. Hughes

10. J. Mike MacDonald

14. T. R. Sharp

15. J. A. Shonder

16. J. J. Tomlinson

17. Laboratory Records-RC

18. Central Research Library

19. Laboratory Records-OSTI

\section{External}

20. Office of Scientific and Technical Information, P.O. Box 62, Oak Ridge, TN 37831

21. Conn Abnee, East Kentucky Power Coop., P.O. Box 707, Winchester, KY 40392-0707

22. James Adams, President, Energy Systems Group, 101 Plaza East Blvd., Ste. 320, Evansville, IN 47715-2804

23. D.K. Adams, Vice President, Mor-Lite of North America, Inc., 7207-A 114th Avenue North, Largo, FL 33773-5121

24. Michael Albertson, ClimateMaster, 4508 Blackberry Run, Oklahoma City , OK 73112

25. Phil Albertson, WaterFurnace International, Inc., 7998 Georgetown Rd \#500, Indianapolis, IN 46268

26. Phil Albertson, Charles Machine Works/Ditch Witch, PO Box 735, Perry, OK 73077

27. Howard Alderson, Alderson Engineering, Inc., 1588 Heather Road, Huntingdon Valley, PA 19006

28. Jay Althof, The Trane Company, 4831 White Bear Parkway, St. Paul, MN 55110

29. Falah Alugaily, ICRC Energy Inc., 10461 White Granite Dr \#225, Oakton, VA 22124

30. David Ames, Jr., Vice President, Virginia Energy Services, 3200 West Moore Street, Richmond, VA 23230

31. John Archibald, Acting Director, Office of Federal Energy Management Programs, U.S. Department of Energy, EE 090, Room 6B-088, 1000 Independence Avenue, SW, Washington, DC 20585

32. Marilyn Arnold, Equitable Resources, $3333 \mathrm{~K}$ Street NW, Washington, DC 20007

33. David Austin, SRS Corp., 5625 Dillard Drive \#101, Cary, NC 27511

34. Charles Aycock, Duke Engineering and Services Inc., P.O. Box 1004, Charlotte, NC 28201-1004

35. John Bailey, Jr., ClimateMaster, 8709 Rail Fence Road, Fort Wayne, IN 46835

36. David Balle, President, UCONS, L.L.C., 3055 112th Ave., N.E., Suite 225; Bellevue, WA 98004-2067

37. Tom Balster, Interstate Power Company Inc., P. O. Box 769, 1000 Main, Dubuque, IA 52004-0769

38. Dan Banard, President, Comprehensive Energy Management, Inc., 230 Lille Lane, Suite 318, Newport Beach, CA 92663

39. Mark Barber, Vice President, Commercial Engineering Corporation, 2890 Dundee Rd., Northbrook, IL 60062-2502

40. John Barlean, Northwest Rural Public Power District, P.O. Box 249, Hay Springs, NE 69347

41. Chip Barnaby, Wright Associates, Inc., 394 Lowell Street, Suite 12, Lexington, MA 02173

42. Marcia A. Barnard, Naval Facilities Engineering Command Contracts Office, Code 27, Bldg. 41, Port Hueneme, CA 93043

43. Kevin Barrett, P.O. Box 270983, Oklahoma City, OK 73137-0983

44. Eddie Barron, Vice President and COO, Utility Engineering Corporation, 5601 I-40 West, Amarillo, TX 79106-4605

45. Monika Bay, Federal Project Manager, Baltimore Gas \& Electric Company, 7225 Windsor Boulevard, Baltimore, MD 21244

46. Freddie Beason, HQ AFCESA/CESE, 139 Barnes Drive, Suite 1, Tyndall AFB, FL32403-5319

47. Michael Beccaria, Director, Government Performance Contracts, ERI Services, 350 Fairfield Ave., Bridgeport, CT 06604 
48. Ned Belt, Jr., Chairman/CEO, Systems Engineering and Management Corporation, 1820 Midpark Rd., Suite C, Knoxville, TN 37921-5950

49. Jeannette Bennion, General Manager, e.three, P O Box 30069, Reno, NV 89520-3069

50. Mark Berman, Director of Business Development, Davis Energy Group, Inc., 123 C Street, Davis, CA 95616

51. Paul Bilbrey, President, Natural Lighting Company, Inc., 7021 W. Augusta \#106, Glendale, AZ 85303

52. Douglas Billiet, ECONAR Energy Systems Corp., 19230 Evans St., Ste. 201, Elk River, MN 5537

53. George Bivens, Delmarva Power, 252 Chapman Rd., P.O. Box 9239, Newark, DE 19714-9239

54. Kenneth Black, Entergy Systems \& Services, 2410 Shrewbury Run, Collierville, TN 38017

55. Stephen Black, Vice President, CONECO Corporation, 280 Summer Street, Boston, MA 02210

56. John Bleem, P.E.Platte River Power Authority, 2000 E. Horsetooth Rd., Fort Collins, CO 80525-5721

57. John Boehme, Manager Technical Sales, Nicor Solutions, 1844 Ferry Road, Naperville, Il 60563

58. Roger Bohon, ENCAP Systems Inc., 1202 Franklin Road, Roanoke, VA 24016

59. Suzette Bollinger, Fall River Rural Electric, 714 Main Street, P.O. Box 830, Ashton, ID 83420

60. James Bose, Oklahoma State University, Engineering Technology, 294 Cordell South, Stillwater, OK 74078

61. Ralph S. Bosek, Executive Vice President, Bosek, Gibson \& Associates, Inc., 508 West Fletcher Avenue, Suite 102, Tampa, FL 33612

62. Jos Bouma, IEA Heat Pump Centre, Swentiboldstraat 1, Box 17, 6137 AE Sittard, Netherlands

63. Sandra Bourdeau, Manager, Govemment Services, Xenergy, Inc., Three Burlington Woods, Burlington, MA $01803-4543$

64. Van Bourne, ClimateMaster, 7300 SW 44th Street, P.O. Box 25788, Oklahoma City, OK 73179

65. Robert Boyer, Pennsylvania Power \& Light Co., 1801 Brookwood St., P.O. Box 1461, Harrisburg, PA 17105-1461

66. Jerry Brandom, UtiliCorp United Inc., 20 West 9th Street MS 7-280, Kansas City, MO 64105

67. Benjamin Brant, President, Planetec Utility Services Company, Inc., 1153 Evergreen Pkwy., Ste. M471, Evergreen, CO 80439

68. Harry Braud, 13519 Bluff Road, Geismar, LA 70734

69. Robert J. Braun, KeySpan Energy Management, Inc., 30 Jericho Executive Plaza, Suite 200C, Jericho, NY $11753-1025$

70. Richard Bremer, EnerShop Inc., 1616 Woodall Rogers Freeway, Dallas, TX 75202

71. Wayne N. Brown, CEO, Planergy, Inc., Barton Oaks Plaza Two, Suite 495, 901 MoPac Expressway South, Austin, TX 78746

72. Robert Brown, ClimateMaster, 4060 N. 100 West, Markle, IN 46770

73. Wyatt Brown, AEP Energy Services, One Riverside Plaza, Columbus, $\mathrm{OH}$ 43215-2355

74. Tim Burke, HydroDelta Corporation, 10205 Gravois, St. Louis, MO 63123

75. Jeff Bush, Vice President, Pacific Enterprises Energy, Services Company, 633 W. Fifth Street, Los Angeles, CA 90071-2006

76. Juan Cabrera, President, Lord \& Company, Inc., 8811 Sudley Rd., Manassas, VA 20110-4728

77. Ralph Cadwallader, Loop Tech International, 607 Highway 19, Huntsvile, TX 77340

78. Douglas Cane, Caneta Research, Inc., Suite 102, Bldg. 2, 7145 W. Credit Avenue, Mississauga, ON L5N 6J7 Canada

79. George Caraghiani, FPL Energy Services, 1982 N. State Rd. 7, Margate, FL 33063

80. Steven Carlson, CDH Energy Corp., PO Box 641, Cazenovia, NY 13035

81. Millard E. Carr, President, Energy Management Solutions, Inc., 9213 Hidden Creek Drive, Great Falls, VA 22066

82. George Cashman, Vice President Financial Products \& Services, Energis Resources, 499 Thomall, Edison, NJ 08837

83. Frank Cassidy, Energis Resources Inc., 499 Thomall Street, Edison, NJ 08837

84. Jim Caughran, ProSolutions, 3101 Carlisle Street, Columbia, SC 29205

85. Harold Chappell, CEO, IllumElex Corporation, 2925 Huntleigh Dr., Ste. 104, P.O. Box 10461, Raleigh, NC 27604

86. Tom Cirello, Government Market Manager, Johnson Controls, Inc., Government Systems Group, 9550 Ridgehaven Court, San Diego, CA 92123-1681

87. Tim Clemons, Executive Vice President of Business Development, Custom Energy, L.L.C., 9217 Cody, Overland Park, KS 66214 
88. Peyton Collie, NRECA, 1800 Mass. Ave., NW, Washington, DC 20036-1883

89. Christopher Condy, Senior Operating Executive, Proven Alternatives, Inc., 1740 Army St., San Francisco, CA 94124

90. Craig Conner, Marketing Manager, Landis \& Staefa, Inc., 1000 Deerfield Pkwy., Buffalo Grove, II 600894513

91. Frank Costanza, President, EnTrust Energy Solutions, 20 W. 9th Street, Kansas City, MO 64105

92. Arthur R. Coughlin, PSCRC9 Campus Drive, Parsipany, NJ 07059

93. Steven Cowell, President, Conservation Services Group, 441 Stuart St., 5th Floor, Boston, MA 02116

94. Bernie Cowsert, Vice President, Conserve-A-Watt Lighting, Inc., 720 Vallejo, Denver, CO 80204

95. Don Creyts, Advanced Geothermal Technologies, P.O. Box 511, Reading, PA 19607

96. Gary Crooks, Avista Advantage Inc., P.O. Box 3727, Spokane, WA 99220

97. James Crossman, President, Financial Energy Management, Inc., 1625 Downing Street, Denver, CO 80218

98. Brian Curran, President/CEO, Energy Conservation Management, Inc., 518 North Charles St., Baltimore, MD 21201

99. Michael Dandrea, AYP Capital, 800 Cabin Hill Dr., Greensburg, PA 15601

100. Charles Davidson, Vice President, Comprehensive Services, Limbach Company, 1005 Alderman Dr., Suite 108, Alpharetta, GA 30005

101. Timothy Davis, Vice President, Services, L.P., dba ServiceMaster Management, 9000 East Nichols Ave., Ste. 150, Englewood, CO 80112-4165

102. Bill Dean, WaterFurnace International, Inc., 9000 Conservation Way, Fort Wayne, IN 46809

103. Diana L. Dean, P.E., Colorado Springs Utilities, 6 North Tejon Street MC 146, P.O. Box 1103, Colorado Springs, CO 80947-1546

104. Rebecca DeLamotte, Vice President, Energy Investment, Inc., One Winthrop Square, 2nd Floor, Boston, MA 02110-1209

105. Sam Dellario, Govemment Projects Director, Viron Corporation, 216 NW Platte Valley Dr., Riverside, MO 64150

106. Karen Den Braven, University of Idaho, Mechanical Engineering Dept., Moscow, ID 83844-0902

107. Jim DePorche, Manager, Energy Project Services, Syska \& Hennessy/CEM, Inc., 11500 West Olympic Blvd., Los Angeles, CA 90064

108. Alan F. Destribats, Xenergy Inc., 3 Burlington Woods, Burlington, MA 01803-4543

109. Leonard DeVanna, COM/Energy Enterprises Inc., One Main Street, Cambridge, MA 02142

110. Joseph J. DeVirgilio, Jr., Central Hudson Gas \& Electric, 284 South Avenue, Poughkeepsie, NY 12601

111. Jack Dienna, Member Services Manager, Geothermal Heat Pump Consortium, Inc., 701 Pennsylvania Avenue, NW, Washington, DC 20004-2696

112. John Dilliplane, Preferred Products Group, 214 W State St., Trenton, NJ 08608-1002

113. David Dinse, Tennessee Valley Authority, Tech Adv., 1101 Market Street, Chattanooga, TN 37402-2801

114. Thomas Dinwoodie, President, PowerLight Corporation, 2954 San Pablo Ave., Berkeley, CA 94710

115. Shawn Dion, Rose Technology Group, Inc., Suite 300 Bldg. 5, Foster Plaza, 651 Holiday Dr., Pittsburgh, PA 15220-2740

116. Bob Dixon, Director Performance Contracting, Landis \& Staefa, Inc., 1000 Deerfield Parkway, Buffalo Grove, Il 60089-4513

117. Bob Dombroski, Wisconsin Power \& Light, 222 West Washington Ave., Madison, WI 53703

118. Floyd Dooris, Central Hudson Enterprises Corp., 110 Main Street, Poughkeepsie, NY 12601

119. William Douglas, Vice President and General Manager, Industrial Energy Applications, Inc., P.O. Box 351, Cedar Rapids, IA 53406

120. Roger Dower, Director, Federal and Special Projects, SYCOM Enterprises, 1010 Wisconsin Ave., N.W., Ste. 340, Washington, DC 20007

121. Patrick Doyle, Vice President, IllumElex Corporation, Suite 104, 2925 Huntleigh Dr., Raleigh, NC 27604

122. Thomas K. Dressen, CEO, Energy Performance Services, Inc., 2003 Renaissance Blvd., King of Prussia, PA 19406

123. M. Michelle Duffy, CPABGE Energy Projects \& Services Inc., 7225 Windsor Blvd., Baltimore, MD 21207

124. Bob Dupuis, Strategic Resource Solutions, 1099 Gum Branch Road, Jacksonville, NC 28540

125. Tom Eckhart, Chief Executive Officer, UCONS, L.L.C., Suite 225, 3055 112th Avenue, NE, Bellevue, WA 98004 
126. Robert F. Edwards, Director, Project Development, Energy Pacific, P. O. Box 502228, San Diego, CA $92150-2228$

127. Bernard Egan, Geo Thermal Plus, Inc., 205 Haven Ct., Lexington, KY 40509-1490

128. Ray Ehmer, HL\&P Energy Services Inc., P.O. Box 4300, Houston, TX 77210-4300

129. Frank Ehrhardt, Director of Alliance Management, Illinova Energy Partners Inc., Suite 305, 1420 Kensington Road, Oak Brook, Il 60521

130. Larry Eitelman, FHP Manufacturing, 565 S. Hudson Ave., Tulsa, OK 74112

131. Dan Ellis, ClimateMaster, 7300 SW 44th Street, P.O. Box 25788, Oklahoma City, OK 73125

132. William Ely, Mammoth, Inc., 341 E. 7th St., Holland, MI 49423

133. Susan Engeleiter, Vice President Government Markets, Honeywell, Inc., Honeywell Plaza, P.O. Box 524, Minneapolis, MN 55440-0524

134. Stephen R. Etsler, NIPSCO Energy Services Inc., 5265 Holman Avenue, Hammond, IN 46320

135. Jeffrey Evans, Vice President, Rieck Mechanical Services, Inc., 5245 Wadsworth Rd., Dayton, OH 45414

136. Garen Ewbank, Geothermal Design and Engineering, Inc., 704 N. Villa, Ste. 100, Oklahoma City, OK 73101

137. Steven Farinha, President, Farinha, Inc., dba Paragon Construction, 12405 Locksley Lane, Auburn, CA 95602

138. Luis Fernandez, Executive Vice President, Imperial Construction \& Electric, Inc., 359 Long Ave., Hillside, NJ 07205-2016

139. Peter M. Feroli, Eastern Utilities Associates, 750 West Center Street, West Bridgewater, MA 02379

140. Philip Fine, P.E., Vice President, Savage-Alert, Inc., 707 Bloomfield Ave., P.O. Box 707, Bloomfield, CT 06002

141. Craig Fischbach, Mammoth, Inc., 101 West 82nd Street, Chaska, MN 55318

142. William S. Fleming, Jacwill Services, Inc., 4571 East Lake Road, Cazenovia, NY 13035

143. Robert Fleming, Director of Utility Partnerships, Energy Masters Corporation, 9101 West 110th St., Ste. 200, Overland Park, KS 66210

144. Frederick G. Florian, BGE Energy Projects \& Services Inc., 7225 Windsor Blvd., Baltimore, MD 21244

145. Michaele Fossum, President, Sun Trapper Solar Systems, Mfg., 12118 Radium St., San Antonio, TX 78216

146. Gustav Foster, Jr., 1240 S. Spring Rd., Vineland, NJ 08361

147. Trevor M. Foster, Executive Vice President, EMCOR Facilities Services Inc., 7th Floor, 101 Merritt 7, Norwalk, CT 06851

148. J. Phillip Frazier, Plum Street Enterprises Inc., 507 Plum Street, Syracuse, NY 13204

149. Morris Friedlander, New York Energy Savers Group, Inc., P.O. Box 154, Brooklyn, NY 11219

150. William Gang, Director, Business Development, The Bentley Company, 1777 Botelho Drive, Suite 350, Walnut Creek, CA 94596-5041

151. James Gardner, President, Gardner Engineering, Inc., 270 Parr Boulevard, Reno, NV 89512

152. William Gary, Executive Vice President, Onsite Energy, 701 Palomer Airport Rd., Ste. 200, Carlsbad, CA 92009

153. Scott W. Gebhardt, PG\&E Energy Services, 353 Sacramento Street \#1900, San Fransisco, CA 94111

154. Randy Gee, President, Industrial Solar Technology Corporation, 4420 Mclyntyre St., Golden, CO 80403

155. Denny George, Sales Manager, FPL Energy Services, Inc., 11770 U.S. Highway One, Golden Bear Plaza, Suite \#500, North Palm Beach, FL 33408-3013

156. Mark Gilbert, President, Energy Solutions, Inc., 618 East Douglas, Wichita, KS 67202

157. David C. Gill, Director of Sales, Siebe Environmental Controls, 1354 Clifford Ave., Loves Park, IL 61111

158. Donald Gilligan, President, CONECO Corporation, 280 Summer St., Boston, MA 02210

159. Richard Gordon, Gordon Associates, 508 SW Jefferson, Corvallis, OR 97333

160. David Graves, Eau Claire Electric Cooperative, 8214 Highway 12, P.O. Box 368, Fall Creek, WI 54742-0368

161. William Greelis, Cinergy Solutions Inc., 139 East Fourth Street, Cincinnati, OH 45202

162. Peter Greenberg, President, Energy-Wise Lighting, Inc., P.O. Box 15443, Washington, DC 20003

163. R. Kirk Gregg, Product Manager, Kansas City Power \& Light Co., P. O. Box 418679, Kansas City, MO 64141-9679

164. Henry Gross, GEI Technologies Itd., 62 Plant Farm Blvd., Brantford, ON N3T-5T7

165. Dan Grover, GPU Advanced Resources Inc., 2675 Morgantown Road Suite GH2-3300, Reading, PA 19607

166. Andy Guarriello, Energy One, 911 Main Street, Kansas City, MO 64105

167. Joseph Gustin, Mid-America Energy Resources Inc., One Monument Circle, Indianapolis, IN 46206-6161 
168. Stephen Guthrie, President, D-Base Communications, Inc., dba, Energy Controls and Concepts, 1758 Orange Tree Lane, Redlands, CA 92374

169. Shane Gydesen, McQuay Intemational, PO Box 1551, Minneapolis, MN 55401

170. Richard Hackner, Energy Center of Wisconsin, 595 Science Drive, Madison, WI 53711-1060

171. Brian Haggart, The Environmental Group, 7300 Southwest $44^{\text {th }}$ Street, Oklahoma City, OK 73125

172. B. James Halpem, Measuring \& Monitoring Services, Inc., 620 Shrewsbury Avenue, Tinton Falls, New - Jersey 07701

173. Don Hamilton, Carolina Power \& Light Co., 1099 Gum Branch Road, Jacksonville, NC 28540

174. Jeff Hammond, WaterFurnace International, Inc., 9000 Conservation Way, Ft. Wayne, IN 46809

175. John Haney, General Manager, FPL Energy Services, Inc., Golden Bear Plaza, Suite 500, 11770 US Highway One, North Palm Beach, FL 33408-3013

176. Darr Hashempour, P.E., Energy Services Program Manager, CH2M HILL, 3 Hutton Centre Drive, Suite 200, Santa Ana, CA 92707

177. Michelle Hayden, President, Energy Applications, Inc., 1565 Hotel Circle South, Suite 360, San Diego, CA 92108

178. Timothy Hayes, General Manager, Aircon Energy, Inc., 4234 North Freeway Blvd., Ste. 100, Sacramento, CA 95834

179. William Heil, All Energy Marketing Company, LLC95 Sawyer Road, Waltham, MA 02154

180. Harold Heiss, 6860 Kilt Ct., Worthington, OH 43085-2129

181. John K. Helbling, IES Utilities Inc., 200 First St. S.E., P.O. Box 351, Cedar Rapids, IA 52401

182. Goran Hellstrom, Dept. Mathematical Physics, Lund University, Box 118, 5-221 00 Lund, Sweden

183. Hugh Henderson, Jr., CDH Energy Corp., P.O. Box 641, Cazeovia, NY 13035-0641

184. Ronald Herbst, Manager of Energy Systems, KDC, Inc. dba KDC Systems, 7700 Pioneer Way, Ste. 103, Gig Harbor, WA 98335

185. Rob Hile, Federal Sales Manager, Control Systems International, Inc. (CSI), 1625 W. Crosby Road, Suite 100, Carrollton, TX 75006

186. Carl Hiller, Manager, Geothermal Heat Pumps and Water Heating, EPRI, 3412 Hillview Ave., P.O. 10412, Palo Alto, CA 94303

187. Stephen Hincks, Vice President, TeleCommunication Systems, 275 West Street, Suite 400, Annapolis, MD 21401

188. Sidney W. Hinton, Southern Development and Investment Group, 64 Perimeter Center, East Atlanta, GA 30346

189. Emest C. Hoelzer, PE, Navy Public Works Center, Code 332 Energy Management Branch, 9742 Maryland Ave., Norfolk, VA 23511-3095

190. John Hollick, President, Conserval Systems Inc., 4242 Ridge Lea Rd. \#1, Buffalo, NY 14226-1051

191. Thomas Holmes, Chairman/CEO, USA Planergy, Inc., 23679 Calabasas Road, Suite 527, Calabasas, CA 91302

192. Walter Hood, GPU Energy, 2800 Pottsville Pike, P.O. Box 16001, Reading, PA 19640-0001

193. Michiel Hoogstede, Puget Sound Energy Services, 26317 Ansell Rd NW, Poulsbo, WA 98370

194. Charles Hopkins, National Sales Manager, Performance Contracting, United Technologies Carrier, Building Systems and Services, 3206 Canterbury Lane, Montgomery, TX 77356

195. John Hopper, President, Valley Air Conditioning \& Repair, Inc., 1350 F Street, Fresno, CA 93706

196. Robert E. Hough P.E., Syracuse Energy, 159 Dwight Park Drive, Syracuse, NY 13209

197. Richard Housh, President, Control Solutions, 1770 Mason Morrow Rd., Lebanon, OH 45036-9298

198. Rodney W. Houston, KU Solutions Corporation, One Quality Street, Lexington, KY 40507

199. Kent Hudson, Knowledge Builders Inc., 111 East Main Street, Coats, NC 27521

200. P. E. Hudson, Vice President, Radian Corporation, P.O. Box 201088, Austin, TX 78720-1088

201. Roger Hurst, Chief Financial Officer, Global EPS LC, 8582 Katy Freeway, Ste. 150, Houston, TX 77024

202. Darcy Immerman, Vice President of Business Development, EUA Cogenex Corporation, Boott Mills South, 100 Foot of John Street, Lowell, MA 01852

203. Ric Johnson, Empire Energy Services, P.O. Box 127, Joplin, MO 64802

204. Scott Jones, Econar Energy Systems Corp., 19230 Evans St. \#201, Elk River, MN 55303

205. John Judge, CONECO Corporation, 280 Summer Street, Boston, MA 02210

206. Phil Kairis, Dakota Energy Altenatives, 4300 220th Street W, Farmmington, MN 55024-9583 
207. Larry Kaufman, Detroit Edison Co., 2000 2nd Ave. 318 WCB, Detroit, MI 48226-1279

208. Steve Kavanaugh, University of Alabama, Box 870276, 290 Hardaway Hall, Tuscaloosa, AL 35487-0276

209. William Kelly Jr., President, FMS Lighting Management Systems, Inc., 323 Commerce Park Dr., P.O. Box 10162, Jackson, MS 39286-0162

210. George Kennedy, President, United Resource Group, Inc., 30311 Clemens Road, Suite 260, Westlake, OH 44145-1023

211. Naresh Khosla, President, EMR, 1901 North Fort Myer Drive, Suite 500, Arlington, VA 22209

212. John Kierzkowski, Spectrum Energy Services Corp., Two North Ninth St., Allentown, PA 18101

213. Jerry Kilby, Kentucky Utilities Company, One Quality Street, Lexington, KY 40507

214. Robert Koschka, WaterFurnace International, Inc., 126 East $48^{\text {th }}$, Indianapolis, IN 46205

215. James P. Kovalcik, PNM Energy Partners, Alvarado Square-BA52, Albuquerque, NM 87158

216. Kathi Kraft, Oglethorpe Power Corporation, 2100 East Exchange Place, P.O. Box 1349, Tucker, GA 30085-1349

217. David Kramka, Johnson Controls Inc., 2400 Kilgust Road, Madison, WI 53713

218. Rich Landy, Entergy Integrated Solutions Inc., 4740 Shelby Drive \#105, Memphis, TN 38118

219. Brett Lawrie, Copeland Corporation, 1675 W. Campbell Road, Sidney, OH 45365-0669

220. Jessica S. Lefevre, 908 King St., Suite 200, Alexandria, VA 22314

221. Franco Lenarduzzi, Ontario Hydro, 800 Kipling Avenue, KR312, Toronto, ON M8Z 5S4 Canada

222. Robert P. Lewis, II, Director, Major Energy Projects, BGE Energy Project \& Services, Inc., 7225 Windsor Boulevard, Baltimore, MD 21244

223. Tom Lewis, Centerprise Inc., One Main Street \#600, Minneapolis, MN 55414

224. Paul Liepe, Geothermal Heat Pump Consortium, Inc., 701 Pennsylvania Ave., NW, Washington, DC 200042696

225. Marilyn Linette, McQuay International, 13600 Industrial Park Blvd., P.O. Box 1551, Minneapolis, MN 55440

226. Edward T. Liston, President, EUA Cogenex Corporation, Boott Mills South, 100 Foot of John Street, Lowell, MA 01852

227. Thomas Londos, Asst. Vice President, Science Applications International Corporation, 4161 Campus Point Court, San Diego, CA 92121

228. Lee Loomis, Rochester Gas and Electric Corp., 89 East Evenue, Rochester, NY 14649-0001

229. Morris Lovett, Group Vice President/Director, Geothermal Design and Engineering, Inc., 704 N. Villa, Suite 100, Oklahoma City, OK 73107

230. Nance Lovvom, Alabama Power / Southern Company, 600 N. 18th St., P.O. Box 2641, Birmingham, AL 35291

231. Andrew Lowenstein, 18 Cameron Ct., Princteon, NJ 08540-3924

232. Alfred Lutz, P.E., Energy Services Group, Atlantic Energy, Inc., 6801 Black Horse Pike, Egg Harbor Township, NJ 08234-4130

233. James Lynn, Director, Business Development, Trigen Development Corporation, One North Charles Street, Baltimore, MD 21201

234. Rudy Lyon, Ingersoll-Rand Co., 7500 Shadwell Drive, Roanoke, VA 24019

235. Guy Lyons, Special Projects Manager, Destec Energy, Inc., 1000 Louisiana, Suite 5800, Houston, TX $77002-5050$

236. John Mahoney, President, Viron Energy Services, 216 NW Platte Valley Drive, Riverside, MO 64150

237. E. John Majkowski, Precision Power Inc., 165 Skiff Street, Hamden, CT 06517

238. Robert Mancini, Mancini, Saldan Associates Ltd., 5468 Dundas St. West, Etobicoke, Ontario M9B 6E3 Canada

239. John Manning, P.E., Water Source Supply Co., P.O. Box 3, Skaneateles, NY 13152

240. Robert Marshall, Plumas-Sierra Rural Electric Coop, 73233 Highway 70, P.O. Box 2000, Portola, CA 96122

241. John U. Martin, TU Electric, 1601 Bryan St., P.O. Box 660268, Dallas, TX 75201

242. David E. Matasek, Manager, Utility Services, Johnson Controls, Inc. Controls Group, 507 E. Michigan Street, P. O. Box 423, Milwaukee, WI 53201-0423

243. Michael F. McGowan, Planergy, U.S. 1 \& 202, Brandywine Two \#300, Chadds Ford, PA 19317

244. Richard A. Michelfelder, Atlantic Energy, 6801 Black Horse Pike, Egg Harbor Township, NJ 08234-4130

245. Frank A. Migneco, GPU Energy, 300 Madison Avenue, PO Box 1911, Morristown, NJ 07962-1911 
246. Phillip M. Mikulsky, WPS Energy Services Inc., 677 Baeten Road, Green Bay, WI 54304

247. Patricia Mishic, Hudson Extrusions, Inc., P.O. Box 255, Hudson, OH 44236

248. Charles Mitchell, Vice President, North American Lighting, Inc., 25057 Anza Drive, Suite B, Valencia, CA 91355

249. John Mitchell, Con Edison Solutions, 701 Westchester Avenue, Suite 210W, White Plains, NY 10604

250. Thomas W. Mitchell, President, Co-Energy Group, Suite N136, 1050 E. Flamingo Road, Las Vegas, NV 89119

251. Michael Montgomery, Managing Director, EnerShop Inc., 1616 Woodall Rodgers Freeway, Dallas, TX 75202

252. Alex Moore, Princeton Economic Research, Inc., 1700 Rockville Pike, Suite 550, Rockville, MD 20852

253. Duncan Morrison, Combined Energies Inc., 41 Anthony Avenue, Augusta, ME 04330

254. Randy Mortensen, Vice President Sales, Energy Masters International, 1385 Mendota Heights Rd., St. Paul, MN 55120

255. Earl Muir, Copeland Corporation, 1675 W. Campbell Road, Sidney, OH 45365-0669

256. Joseph Mulloney, Jr., P.E., CEM, Senior Engineer, EA Engineering, Science, and Technology, Inc., 11019 McCormick Rd., Hunt Valley, MD 21031

257. David Munn, Southwest HEC, 1232 E. Broadway Road, Tempe, AZ 85282-1509

258. Jay Murphy, K \& M Shillingford, Inc., 5004 E. Archer, Tulsa, OK 74115

259. William Murphy, University of Kentucky/Ag Engr. Dept., 128 Ag Engr. Building, Lexington, KY 405460276

260. Patrick J. Murray, Mich Con, 500 Griswold, Detroit, MI 48038

261. Gordon Nelson, Addison Products Company, 7050 Overland Road, Orlando, FL 32810

262. Richard Niess, Gilbert \& Associates, Gloucester Pt Office Plaza, Suite D, 1811 G. Washington Mem Hwy, Gloucester Point, VA 23062

263. Robert Noonen, Energy Services Manager, Siebe Environmental Controls, Division of Barber-Colman Company, 1354 Clifford Ave., Loves Park, IL 61111

264. Joe Norton, St. Joseph Light \& Power Co., 520 Francis St., P.O. Box 998, St. Joseph, MO 64502-0998

265. Jim Nuemberger, Senior Contract Administrator, Illinova Energy Partners, 500 South 27th Street, P.O. Box 511, Decatur, II 62525-1805

266. Thomas O'Day, Today Assoc., Inc., 500 S. Salina St., Syracuse, NY 13202

267. Richard O’Neil, Niagara Mohawk Power Corporation, 507 Plum Street, P.O. Box 5001, Syracuse, NY 132505001

268. Paul Ogle, Knowledge Builders Inc., 111 East Main Street, Coats, NC 27521

269. Paul Ogle, Strategic Resource Solutions, Suite 101, 5625 Dillard Dr., Cary, NC 27511

270. Arthur N. Olson, American Electric Power, One Riverside Plaza 27th Floor, Columbus, OH 43215

271. Carl Orio, Water \& Energy Systems Corp. - ClimateMaster, 100 Maple Ave., Atkinson, NH 03811

272. Greg Orman, Custom Energy LLC, 6409 City West Parkway, Eden Prairie, MN 55344

273. Ken Ormsbee, Director, Federal and Defense Markets, Energy Masters Intemational, Inc., 1385 Mendota Heights Road, St. Paul, MN 55120-1128

274. Thomas Ott, Palisades Energy Services Inc., One Blue Hill Plaza, Pearl River, NJ 10965

275. Timothy Otto, Director of Strategic Alliances, Edison Source/Edison International, 13191 Crossroads Parkway North \#405, City of Industry, CA 91746

276. G. Ronald Owens, Mid America Drilling Equipment, Inc., 5802 SW 6th Place, Ocala, FL 34474

277. Fred Paepke, Bard Manufacturing Co., 1914 Randolph Dr., P.O. Box 607, Bryan, OH 43506

278. Greg Page, Vice President, Abacus Engineered Systems, Inc., 401 Second Avenue South \#201, Seattle, WA 98104

279. Steve Paiewonsky, HydroDelta Corporation, 5 Pocono Heights, E. Stroudsburg, PA 18301

280. Daniel W. Parke, President, Parke Industries, Inc., 2246 Lindsay Way, Glendora, CA 91740

281. Thomas Patemo, Vice President of Energy Services, Southland Industries, 1661 E. 32nd Street, Long Beach, CA 90807

282. Robert Payne, Director, Federal Energy Services, DukeSolutions, Inc., 230 South Tryon St., Suite 400, Charlotte, NC 28202

283. Stephen Pazian, Edison Source, 13191 Crossroads Parkway N \#405, City of Industry, CA 91746

284. George Penn, Global Energy Options, 4634 Bonner Lane, Madison, WI 53704-1327 
-285. Gary Phetteplace, U.S. Army Cold Regions Lab, 72 Lyme Road, Hanover, NH 03755-1290

286. Thomas W. Philbin, President, HEC Energy Corporation, 24 Prime Parkway, Natick, MA 01760

287. David Phillips, Proposal Development Manager, Combined Energies, 41 Anthony Avenue, Augusta, ME 04330

288. R. A. (Tony) Pierce, Southern California Edison, 300 North Lone Hill Ave., San Dimas, CA 91773

289. Alan Pong, President, Ferreira Service, Inc., 2566 Barrington Court, Hayward, CA 94545

290. Ted Pope, Pacific Gas \& Electric, 123 Mission St Rm 2284, P.O. Box 770000 MC H28L, San Francisco, CA 94177

291. Lew Pratsch, U.S. Department of Energy, 1000 Independence Ave., S.W., Code 342, Washington, DC 20585

292. Pete Prydybasz, HydroDelta Corporation, 2352A Wentzel Rd, RD 2, Mohnton, PA 19540

293. James Quigley, Public Service of New Mexico, Alvarado Square-MS BA52, Albuquerque, NM 87158

294. Michael J. Quigley, E Prime, 1331 17th Street \#201, Denver, CO 80202

295. Kevin Rafferty, GEO Heat Center, Oregon Institute of Technology, 3201 Campus Drive, Klamath Falls, OR 97601

296. John Ramill, Bosek Gibson and Associates, 508 West Fletcher Avenue, Tampa, FL 33612

297. Curtis Ranger, President, Biomass Energy Systems, Inc., P.O. Box 8641, 425 S. Main Street, Suite 201, Ann Arbor, MI 48107

298. Scott Rankert, Entech Sales \& Service, Inc., 3404 Garden Brook Dr., Dallas, TX 75234

299. Phil Rawlings, The Rawlings Company, 2308 Watchill Dr., Greenville, TX 75402-6444

300. Philips Reese, Conectiv Service, P.O. Box 6066, Newark, DE 19714-6066

301. Francis Reilly Jr., President, Harris Energy Systems, 66 Long Wharf, Boston, MA 02110

302. Charles Remund, South Dakota State University, 210B CEH, ME Dept., Brookings, SD 57007

303. Manfred Reuss, Technische Universität München, Bayer. Landesanstalt für Landtechnik, Vöttinger Strasse 36, Freising, Germany D-85354

304. Michael J. Richards, Chotawhatchee Electric Coop. Inc., 1350 W. Baldwin Ave., P.O. Box 512, DeFuniak Springs, FL 32433

305. Randy Richgruber, Minnesota Power Company, 30 W Superior St., Duluth, MN 55802

306. Russell Riley, ESPC Manager, Mason \& Hanger-Silas Mason Co., Inc., First National Bank Building, Suite 420, 701 South Taylor Street, Amarillo, TX 79101

307. Richard Rinck, Atlantic Electric, 6801 Black Horse Pike, Egg Harbor Township, NJ 08234-4130

308. John Rinehart, President, Industrial Electric Corporation, P.O. Box 1188, Beaver, WV 25813

309. John Rizzo, PE, Vice President, Northeast Energy Services Company (Noresco), Point West Place, 111 Speen St., Ste. 500, Framingham, MA 01701

310. David Robb, Rose Technology Group, Inc., 651 Holiday Drive, Suite \#300, Pittsburgh, PA 15220-2740

311. Ronald A. Robertson, Energy Performance Services Inc., 2003 Renaissance Blvd., King of Prussia, PA 19406

312. Wayne Robertson, PE, CEM, Director of Energy Consulting, Heery International, Inc., 999 Peachtree St., NE, Atlanta, GA 30367-5401

313. Scott H. Rollings, T. C. Technologies, 6757 Paljay Court, Las Vegas, NV 80117

314. Blake W. Ross, Director, Business Development, Governmental \& Industrial EnergyUSA, P. O. Box 1200, Brattleboro, VT 05302

315. David Ross, Policy Research Assoc., Inc., 11260 Roger Bacon Drive, Ste. 206, Reston, VA 22090-5203

316. Samuel Roth, President, Roth Bros., Inc., 3847 Crum Rd., P.O. Box 4209, Youngtown, OH 44515

317. Frank Rotondi, MP Energy Services Company, 40 East Broadway, Butte, MT 59701

318. Arlo Rude, City of Thief River Falls, P.O. Box 528, Thief River Falls, MN 56701

319. Harvey Sachs, Geothermal Heat Pump Consortium, 701 Pennsylvania Ave, $3^{\text {rd }}$ Floor, Washington, DC 20004-2696

320. Tanya Sadler, Office of Federal Energy Management Programs, U.S. Department of Energy, EE 090, 1000 Independence Avenue, SW, Washington, DC 20585

321. Stephen P. Sain, PE CE, Sain Engineering Assoc., Inc., 2820 Columbiana Rd., Ste. 100, Birmingham, Al 35216

322. George P. Sakellaris, President \& CEO, NORESCO, Point West Place, 111 Speen Street, Framingham, MA 01701 
323. Chris Salzmann, Manager, Performance Contracting, Westar Business Services, 818 Kansas Avenue, Topeka, KS 66612

324. James Samis, President, Thermonetics, Inc., 101 E. Park Blvd., Suite 543, Plano, TX 75074

325. Burkhard Sanner, Geothermal Association, Gartenstrasse 36, Geeste, Germany D-49744

326. B. Y. Sarandah, Vice President and Manager, Bechtel National, Inc., 45 Fremont Street, P.O. Box 193965, San Francisco, CA 94119-3965

327. Sanjiv Saste, President, Energy Conservation Specialists, Inc., 5425 Theresa Road, Suite G., Tampa, FL 33615-3813

328. Ken Schedin, Vice President, Sylvania Lighting Services Corp., 100 Endicott Street, Danvers, MA 01923

329. Nancy Schibonski, Northern States Power - MN414, Nicollet Mall RS-55, Minneapolis, MN 55401

330. Penry Schmidt, President, Energy Services Group, L.L.C., 2335 Nevada Ave. North, Minneapolis, MN 55427

331. Phil Schoen, Geo Enterprises, 308B W. Red Bird, Broken Arrow, OK 74012

332. Richard E. Schonbachler, Baltimore Gas \& Electric Co., 7130 Rutherford Road, Baltimore, MD 21244

333. David Schrier, President, Management \& Business Associates, Inc., 6595 NW 36th Street, Suite C 309, Miami, FL 33166

334. Dean Schultzbank, P.E., Federal Accounts Manager, Wisconsin Electric Company, 231 West Michigan Avenue, Milwaukee, WI 53201

335. Robert Schultz, Illinova Energy Partners, 1420 Kensington Road \#305, Oak Brook, IL 60521

336. Joe Schwartzenberger, Manager of Operations, The Montana Power Trading and Marketing Company, 16 East Granite Street, Butte, MT 59701-9326

337. Bill Scribner, OG\&E, 101 N. Robinson, Oklahoma City, OK 73102

338. Vicki Severson, Otter Tail Power Co., 215 South Cascade, P.O. Box 496, Fergus Falls, MN 56537

339. Christopher S. Sharpe P.E., Duke Power Company, 526 S. Church St EC12F, P.O. Box 1006, Charlotte, NC 28201-1006

340. Rita Sharpe, Westar Energy, 818 Kansas Avenue, Topeka, KS 66612

341. Craig Shephard, QST Energy Inc., 300 Hamilton Blvd. \#300, Peoria, IL 61602

342. Michael S. Sherber, P.E.Sherber Associates Inc., 20 Woodmont Rd., Avon, CT 06001

343. William Shivly, CMS Marketing Services and Trading, One Jackson Square Suite 1060, Jackson, MI 49201

344. Duane Shover, Enertech Inc., 220 West Main, Louisville, KY 40202

345. A. Glenn Simpson, PEPCO Services Inc., 2000 K Street N.W. \#750, Washington, DC 20006

346. Andy Sinclair, Carrier Corporation, P.O. Box 70, Indianapolis, IN 46206

347. Jitendra Singh, 14 Kory Drive, Kendall Park, NJ 08824-1608

348. Steve Siverson, Business Unit Manager, J. B. Rodgers Performance Contracting, 706 East Bell Rd., Ste. 206, Phoenix, AZ 85022

349. Daniel P. Skaar, General Manager, NI Energy Services Company, 802 Canonie Dr., Porter, IN 46304

350. Allan Skouby, GeoPro, Inc., 1444 Rogers Ct., Allen, TX 75013

351. Carmen Smargiassi, PECO Energy, 2301 Market Street S7-4, P.O. Box 8699, Philadelphia, PA 19101

352. Chris Smith, FHP Manufacturing, 601 N.W. 65th Court, Ft. Lauderdale, FL 33309

353. Cristy S. Smith, FirstEnergy, 76 S. Main Street, Akron, OH 44308

354. Donald O. Smith, Energy Masters Corp., 9101 W. 110th St \#200, Overland Park, KS 66210

355. Marvin Smith, Oklahoma State University, GHP Research, 499 Cordell South, Stillwater, OK 74078

356. Robert Smith, Commonwealth Edison, 1919 Swift Road, Oak Brook, IL 60521

357. Janey Sorensen, Delta-Montrose Electric Association, 121 E 12th St., P.O. Box 59, Delta, CO 81416

358. Scott D. Souza, Noresco, 111 Speen Street, Framingham, MA 01701

359. Richard T. Sperberg, President, Onsite Energy Corporation, Suite 200, 701 Palomar Airport Road, Carlsbad, CA 92009

360. Judy Spinner, Kansas City Power \& Light Co., 1201 Walnut 20th Fl., Kansas City, MO 64106

361. Jeffrey Spitler, Oklahoma State University, School of Mechanical \& Aerospace Engineering, Engineering North 218, Stillwater, OK 74078

362. Russell Spitz, Ph.D., Senior Vice President, Vision Impact Corporation (VIC), 3733 Crown Point Road, Jacksonville, FL 32257

363. Lisa Staggs, Butler REC Inc., 3888 Stillwell-Beckett Road, Oxford, OH 45056

364. Bobby Starling, CEHNC-PM-CR, Huntsville Division, U. S. Army Corps of Engineers, P.O. Box 1600, Huntsville, AL 35807-4301 
365. Ray Starling, HEI Power Corporation, P.O. Box 3160, Honolulu, HI 96802

366. Pam Bard Steel, Bard Manufacturing Co., 1914 Randolph Dr., P.O. Box 607, Bryan, OH 43506

367. Charles B. Steen, Director, Entergy Retail Services, Inc., P. O. Box 1640, Jackson, MS 39215-1640

368. Lynn Stiles, Richard Stockton College of New Jersey, NAMS/Stockton College; P.O. Box 195, Pomona, NJ 08240-0195

369. Donna Stoughton, Charter Plastics, Inc., P.O. Box 770, Titusville, PA 16354

370. James Sugden, Lehr Associates, 20 Park Plaza \#467, Boston, MA 02116

371. William Sullivan, 324 Hermosa Dr. SE, Albuquerque, NM 87108-2614

372. John Summers, Government Marketing Manager, Entergy Integrated Solutions, Inc., 3838 N. Causeway Blvd. Suite 3400, Metairie, LA 70002

373. Stephen Sunderhauf, Potomac Electric Power Co., 1900 Pennsylvania Ave NW, Room 842, Washington, DC 20068

374. S. Lynn Sutcliffe, President and CEO, SYCOM Enterprises, First Floor, 27 Worlds Fair Dr., Somerset, NJ 08873

375. Kenneth Swan, General Manager, Performance Contracting, Building Controls \& Services, Inc., 4 Peuquet Parkway, Tonawanda, NY 14150

376. Sam Tadros, President, Super Systems, Inc., 17561 Teachers Ave., Bldg. A, Irvine, CA 92614

377. Vance Tang, National Manager-PACT, The Trane Company, a Division of American Standard, Inc., Asset Management Services, 4831 White Bear Parkway, St. Paul, MN 55110

378. Daniel Tarkington, P.E., President, Four Seasons Environmental, 849 Cannes Court, Loveland, OH 451409497

379. Jay Taylor, Manager, Government Services, LighTec, Inc., 25 Depot St., Merrimack, NH 03054

380. Greg Tech, Cresline Plastic Pipe Co., Inc., 2100 S 35th Street, Council Bluffs, IA 51501

381. Woodman Teele, Engineering Manager, General Electric Company, Motors and Industrial Systems, 2101 Executive Dr., \#60, Hampton, VA 23666

382. Scott Terrell, Truckee Donner PUD, P.O. Box 309, Truckee, CA 96160

383. Tom Thomas, Dixie Escalante REA, 145 W. Bringham Road, St. George, UT 84790

384. Jeff Thornton, Thermal Energy System Specialists, 5610 Medical Circle, Suite 31, Madison, WI 53719

385. Steven Tillman, Manager, Morrison Construction Services, Inc., 1990 Saint Street, Richland, WA 99352

386. John Tipton, Manager, Commercial Services, HL\&P Energy Services Company, P.O. Box 4300, Houston, TX 77120-4300

387. Ellen Trick, Trane Company, P.O. Box 7916, Waco, TX 76714-7916

388. B. N. Tripathi P.E., CES/Way International Inc., 5308 Ashbrook, Houston, TX 77081

389. Jerry Troyer, President, American Illuminetics, Inc., 5940 Darwin Court, Carlsbad, CA $92008-7372$

390. Darryl Tveitbakk, Northern Municipal Power Agency, 123 North Main Avenue, P.O. Box 528, Thief River Falls, MN 56701-0528

391. Mutch Usera, Black Hills Power \& Light Co., P.O. Box 1400, Rapid City, SD 57709

392. Gary Valli, Allegheny Power, 800 Cabin Hill Dr., Greensburg, PA 15601

393. Len van Essen, Lennox Industries, Inc., 1600 Metrocrest, P.O. Box 110877, Carrollton, TX 75011-0877

394. David Van Hersett, Vice President, Northwest Energy Services, Inc., 9 South Washington, Suite 500, Spokane, WA 99201

395. Gary VonFischer, Director of Govemment Entities, Enron Energy Services Operations, Inc., 400 Metro Place North, Dublin, OH 43017-3375

396. Joel Wagner, Southwest Energy Solutions Inc., P.O. Box 711, Tucson, AZ 85702

397. Fred Wajcs, Northeast Utilities, P.O. Box 270, Hartford, CT 06141-0270

398. Bernard Walker, York International Corp., 2675 Eisenhower Ave., Norristown, PA 19403-2398

399. John Walker, Mobile Drill Co., 3807 Madison Ave., Indianapolis, IN 46227

400. Mike Wallace, Maine Public Service Company, P.O. Box 120910, Parkhurst Siding Rd., Presque Isle, ME 04769-1209

401. John Welch, Secure Energy Inc., One Northshore Center, Pittsburgh, PA 15212

402. Prof. M. W. Wildin, University of New Mexico, Department of Mechanical Engineering, Albuquerque, NM 87131

403. Barry Wilhelm, Virginia Power, 701 E. Cary Street 8th Floor, P.O. Box 26666, Richmond, VA 23261

404. Bob Williamson, Addison Products Company, 7050 Overland Road, Orlando, FL 32810 
405. Dennis Wilson, President, Enersave, Inc., 355 Lexington Ave., 19th Floor, New York, NY 10017

406. Kerry R. Wilson CEM CLEP, Evantage, One James River Plaza 7th Fl., 701 E. Cary St., Richmond, VA 23219

407. Kerry Wilson, Product Manager, Evantage, a Division of Virginia Power, 5000 Dominion Blvd., 3 SE, Glen Allen, VA 23060

408. Buddy Winslow, Winslow Pump and Well, Inc., P.O. Box 521, Hollywood, MD 20636

409. - Brian Wolka, Jackson County REMC, 274 E. Base Rd., P.O. Box K, Brownstown, IN 47220-0311

410. Bernie Woller, Buckeye Power, Inc., P.O. Box 26036, Columbus, OH 43226-0036

411. Richard Wright, American Thru Wall Manufacturing Corp., 59-BC Remington Boulevard, Ronkonkoma NY 01179

412. Margaret Wyers, Crispaire Geothermal Heat Pumps, 3285 Saturn Ct. NW, Norcross, GA 30092

413. Raymond Zawadzki, CPCM, Contracts Manager, Strategic Resource Solutions Corp., 5625 Dillard Rd., Suite 101, Cary, NC 27511

414. Jon Zellhoefer, Principal Engineer, FMCS Energy Services, 30601 Avenue Seven, Madera, CA 93637 